IZA DP No. 9393

Labor Force Activity after 60:

Recent Trends in the Scandinavian Countries with Germany as a Benchmark

Mona Larsen

Peder J. Pedersen

September 2015 


\title{
Labor Force Activity after 60: Recent Trends in the Scandinavian Countries with Germany as a Benchmark
}

\author{
Mona Larsen \\ Danish National Centre for Social Research (SFI) \\ Peder J. Pedersen \\ Danish National Centre for Social Research (SFI), \\ Aarhus University and IZA
}

\section{Discussion Paper No. 9393 \\ September 2015}

\author{
IZA \\ P.O. Box 7240 \\ 53072 Bonn \\ Germany \\ Phone: +49-228-3894-0 \\ Fax: +49-228-3894-180 \\ E-mail: iza@iza.org
}

Any opinions expressed here are those of the author(s) and not those of IZA. Research published in this series may include views on policy, but the institute itself takes no institutional policy positions. The IZA research network is committed to the IZA Guiding Principles of Research Integrity.

The Institute for the Study of Labor (IZA) in Bonn is a local and virtual international research center and a place of communication between science, politics and business. IZA is an independent nonprofit organization supported by Deutsche Post Foundation. The center is associated with the University of Bonn and offers a stimulating research environment through its international network, workshops and conferences, data service, project support, research visits and doctoral program. IZA engages in (i) original and internationally competitive research in all fields of labor economics, (ii) development of policy concepts, and (iii) dissemination of research results and concepts to the interested public.

IZA Discussion Papers often represent preliminary work and are circulated to encourage discussion. Citation of such a paper should account for its provisional character. A revised version may be available directly from the author. 
IZA Discussion Paper No. 9393

September 2015

\section{ABSTRACT \\ Labor Force Activity after 60: Recent Trends in the Scandinavian Countries with Germany as a Benchmark}

In most OECD member countries labor force attachment has increased in recent years in the $60+$ group. Focus in the paper is on the development in this area in Denmark, Norway and Sweden since the 1990s. The development in the same period in the German labor market is included as a frame of reference. Main emphasis is given to the development in two distinct age groups, i.e. people in the first half of the 60 s of which many are eligible for early retirement programs and people older than 65 mostly eligible for social security retirement programs. For these two age groups the actual development in labor force participation is described based on register data and on labor force surveys along with indicators of cohort relevant changes in education and health. Focus in the paper includes also the gender aspect to accommodate stronger cohort effects for women than for men. The impact on labor force participation from individual education and from self-assessed health is analyzed based on available micro data. Policy reforms and changes in the retirement area have been enacted since the mid-1990s in the included countries and more sweeping reforms are enacted or under review for the years ahead. We include a brief survey of policy changes in the Scandinavian countries and Germany as other determinants of labor force participation in the 60 and older group.

JEL Classification: I15, I25, J14, J26

Keywords: employment, older workers, health, education, program changes

Corresponding author:

Peder J. Pedersen

Department of Economics and Business

Fuglesangs Allé 4

8210 Aarhus V

Denmark

E-mail: ppedersen@econ.au.dk 


\section{Introduction}

The great recession beginning in 2008 resulted in a very dramatic decline in real GDP in Denmark followed by a slow recovery to a current situation with real GDP close to the same level as just before the crisis began. At the same time the recession resulted in a big decline in aggregate employment in the Danish economy. A surprising fact in light of these events is the finding that the share in employment has gone up from 2008 to 2014 for one age group, the 60-64 years old. For those younger than 60, there is a steep negative gradient for still younger age groups. This is obviously a surprising finding during a big and long recession where prior expectations would be above average reduction in employment among older workers along with increasing exit to unemployment and early retirement in the age group above 60. However, increasing evidence shows that this surprising finding is common for most OECD countries. Further, increasing labor force participation in the 60 and older group began in the mid-1990s and has in spite of the recession continued after 2008. Another surprising finding is that the increasing labor force participation reflects an increase in the share of people in the age group with a job and not a strong increase in unemployment.

Focus below is on these tendencies in the three Scandinavian countries, Denmark, Norway and Sweden including evidence also for the development in Germany. It is, however, relevant first to emphasize the broad international trend in the improved labor market situation for older workers continuing since 2008, i.e. during the deepest recession since 1945. OECD (2013) presents a survey of some of the factors assumed to lie behind this trend. The economic incentives to stay longer in the labor market have become stronger. This is a reflection of many policy changes intending to reduce the implicit tax on continued work at older ages. At the same time each new cohort of older workers are better educated and by available indicators they also appear to be in better health, both potential factors in explaining longer working lives. Another factor is the changing nature of jobs over time regarding hard physical work which is becoming less important due to technological changes and the shift to jobs in the service sector. While these changes have improved the possibilities for older workers to continue in the job, other job related factors like stress and fast changes in technology and job functions might work in the opposite direction. Finally, those mainly supply oriented factors are not the full explanation of the trend among older workers. A supply driven behavior must obviously meet a demand, i.e. employers that keep older workers, even in a setting of a very deep recession. A discussion of the demand aspect can for instance be found in Dalen et al. (2010). A discussion based on the experience in Germany can be found in Brusch and 
Büsch (2012) and in Ditterich et al. (2011). In Germany the forecast is a decline in the working age population (20-64 years old) of 12.7 per cent from 2013 to 2030 which is even bigger than the declines forecasted for the southern European countries (EU Commission) implying that employment trends among older workers are of especially high relevance here.

The trend towards longer working lives is a positive mechanism in adaptation to the demographic changes occurring in the next decades in most OECD countries. One caveat, however, could be an eventual harmful effect on the employment prospects for young people in a situation where older workers postpone retirement. OECD (2013) collects evidence on this so called lump-of-labor theory. The conclusion, based on earlier studies, e.g. Gruber and Wise (2010) presenting results for 12 countries, and an independent new analysis in OECD (2013) is that no support is found for the idea of older workers keeping young people out of jobs. Longer working lives, then, appears to be a genuine help in accommodating the coming demographic change. A recent survey of changes in employment rates among older workers in the OECD countries can be found in Larsen and Pedersen (2013) while a study with focus on Europe can be found in Anxo et al. (2012). Aspects of the experience in recent years in Germany can be found in Brenke (2012), Brenke and Zimmermann (2011) and Hochfellner and Burkert (2013). An interesting description of the changing attitudes to work at older ages can be found in Der Spiegel $(2014,21)$

In the following, Section 2 contains a survey of the types of data used in the subsequent descriptions and analyses. Next, Section 3 describes the aggregate development in labor force participation in the Scandinavian countries based on population wide data from administrative registers and labor force surveys. Further, Section 3 summarizes indicators of the changes in education and health for the 60-69 years old from 1993 to 2013. While the focus in Section 3 is on more aggregate data, focus shifts in Section 4 to available micro data sets with individual information on education and self assessed health to be among the important determinants of labor market participation. Data used in Section 4 are the Danish Longitudinal Survey of the Ageing (DLSA), the German Socioeconomic Panel (GSOEP), SHARE data and data from the European Community Household Panel (ECHP). Section 5 contains a brief survey of retirement policy changes in the Scandinavian countries and Germany since the mid-1990s trying to identify an impact on major changes in the development described in the preceding sections. Finally, Section 6 concludes the paper with a discussion of the results. 


\section{Data Sources}

In most countries labor force participation rates are the outcome of labor force surveys taken on representative samples. In the three Scandinavian countries the main source for aggregate labor force data is, however, population wide information based on administrative registers. The initial aggregate overview of labor force participation in the 60 and older group presented for the Scandinavian countries below is based on register data. One clear advantage using register data is the coverage of the whole population including information by age, gender and occupation. A disadvantage compared to survey data is the absence of answers to questions about attitudes, search behavior, health etc. reducing the extent of unobserved heterogeneity.

Labor force participation in the 60 and older group is expected to depend crucially on education and health, both factors changing over time with still more recent cohorts of workers. The aggregate register data enables us to calculate the change over time in education by age and gender for the population 60 and older and in some cases to calculate the change in education separately for those in the labor force, cf. below. One major challenge with aggregate register data is however the lack of a general individual health indicator. Below, we briefly use expected life time at 65 as a broad indicator of the state of health.

With the purpose of going deeper into the interaction between education and health at an individual level we use a number of micro panel data sets to decompose this interaction as primary determinants of labor force participation along with the potential impact from policy changes and reforms in the retirement area.

We are drawing information from four different micro data sets. For Denmark we have access to the Danish Longitudinal Survey of the Ageing (DLSA) which is a survey based panel collected every 5 years since 1997 on the cohorts being 62, respectively 67 years old. We have access also to Danish data from the European Community Household Panel (ECHP). Further, we use the German Socioeconomic Panel (GSOEP), a panel running from 1984. Finally, we use the Survey of Health, Ageing and Retirement in Europe (SHARE) to decompose the impact on labor force participation from education and health in Denmark, Germany and Sweden in 2011. For the three micro data sets the health variable is self assessed health (sah).

The register data as well as the micro data sets apply in principle ILO criteria to the classification of individuals in relation to the labor force. In this way individuals may have entered an early or normal age retirement program but still be working to an extent where they are classified as being in the labor force. Furthermore, individuals can enter a retirement program, have a spell completely 
without any work activity and then re-enter the labor market to a job, the so called un-retirement behavior. Next, in Section 3 the focus is on the aggregate trend in labor force participation among 60-64 and 65-69 years old women and men in the Scandinavian countries..

\section{Development in LFP rates in the 60+ group in the Scandinavian countries}

The three Scandinavian countries share a number of similarities, i.e. ambitious welfare states based on a large public sector, high taxes, fairly generous and mostly universal benefit programs, and high labor force participation for women. But at the same time they differ in a number of respects such as industrial structure, cyclical experience during recent decades and retirement policies.

A summary overview of the initial level and the relative change in aggregate employment rates from 1995 to 2013 for the 60-64 and the 65-69 years old is shown in Figure 1 based on labor force surveys. For comparison Figure 1 also includes the experience in Germany and Iceland, being “outliers” relative to the three Scandinavian countries. In Germany the initial level is low for both age groups while the relative increase is tremendous.

The other extreme, Iceland, illustrates the very high initial level along with the impact from the great recession, which - as well known - was very hard on the Icelandic economy. It is interesting, however, to note that even after the great recession, while Iceland does not share in the international trend towards increasing labor force participation among older workers, the level is still among the highest in the world. 
Figure 1. Employment rates 1995 and relative change until 2013, 60-64 and 65-69 years old. Germany and four Nordic countries (calculations from Eurostat database).

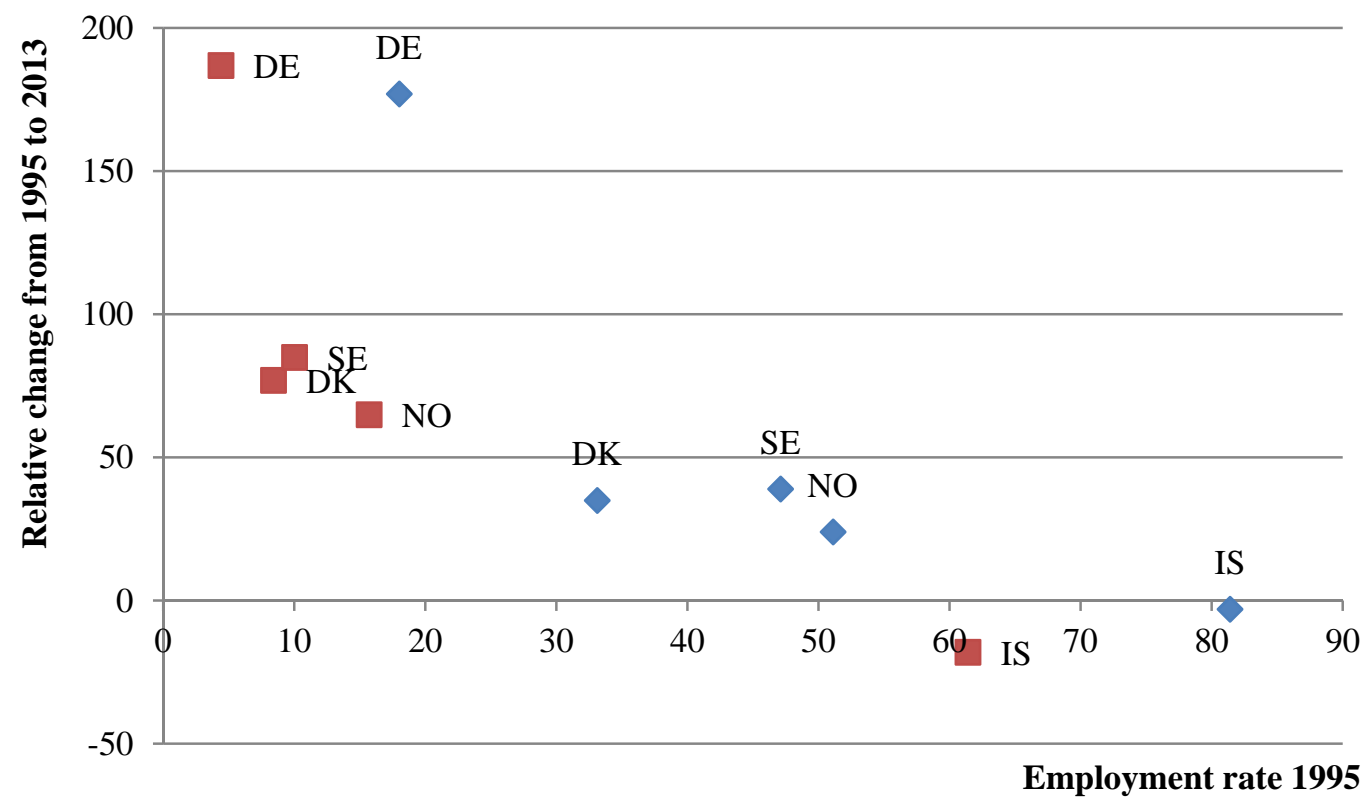

$\diamond 60-64 \square 65-69$

Next, Figures 2-7 show the profiles in labor force participation in the two age groups, separately for women and men, over the years 1993 to 2013. For Denmark and Sweden data are from administrative registers covering the whole population or are based on calculations on register data. For Norway register data in this area are only available from 2004. Instead we use data from Norwegian labor force surveys ${ }^{1}$.

In all three countries the turning point where labor force participation rates begin to go up is around the year 2000. After a short setback in the initial phase of the great recession, labor force participation rates continue on an upward trend. The increase differs between the countries reflecting differences in GDP growth rates and early retirement options. Over the whole 20-year period, the increase in Sweden is much stronger than in the other two countries, with an increase for both men and women of about 25 percentage points in the 60-64 years old group and about 15 - 20 percentage points for the 65-69 years old. In Denmark and Norway, the picture is somewhat different. For 60-64 years old, the increase is about 15 percentage points for men and 20 percentage points for women in Denmark while it is in the range 10-15 percentage points in Norway. For the

\footnotetext{
${ }^{1}$ For Norway data for the oldest age group are for the 65-74 years old as data are not readily available for the 65-69 years old.
} 
older age group, the increase is stronger in Norway than in Denmark which is remarkable as the age interval for Norway is up to the mid-70s

The level of labor force participation rates is about 10 percentage points higher for the 60-64 years old men in Norway and Sweden compared to Denmark. For women the levels in Norway and Sweden are about 20 percentage points higher than in Denmark. While part of these differences may reflect differences in GDP growth rates over the period, another part most probably reflects a more attractive early retirement option in Denmark during this period. For the whole period 19932013, average economic growth in Denmark was about 1 percentage point lower than the average in Norway and Sweden, and at about the same level as in Germany, see Figures A1 and A2 in the Appendix.

Figure 2. Labor force participation rates, 60-64 years, Denmark 1993-2013.

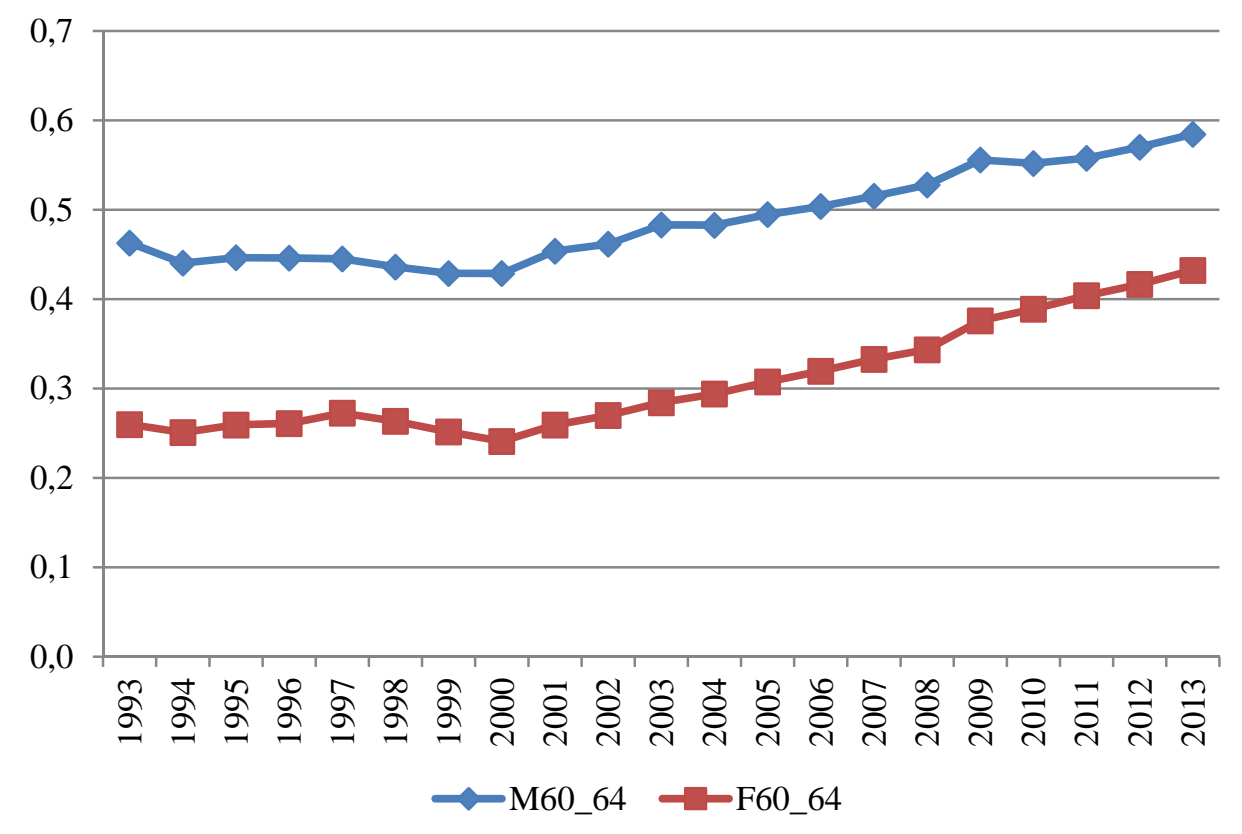


Figure 3. Labor force participation rates, 65-69 years, Denmark 1993-2013.

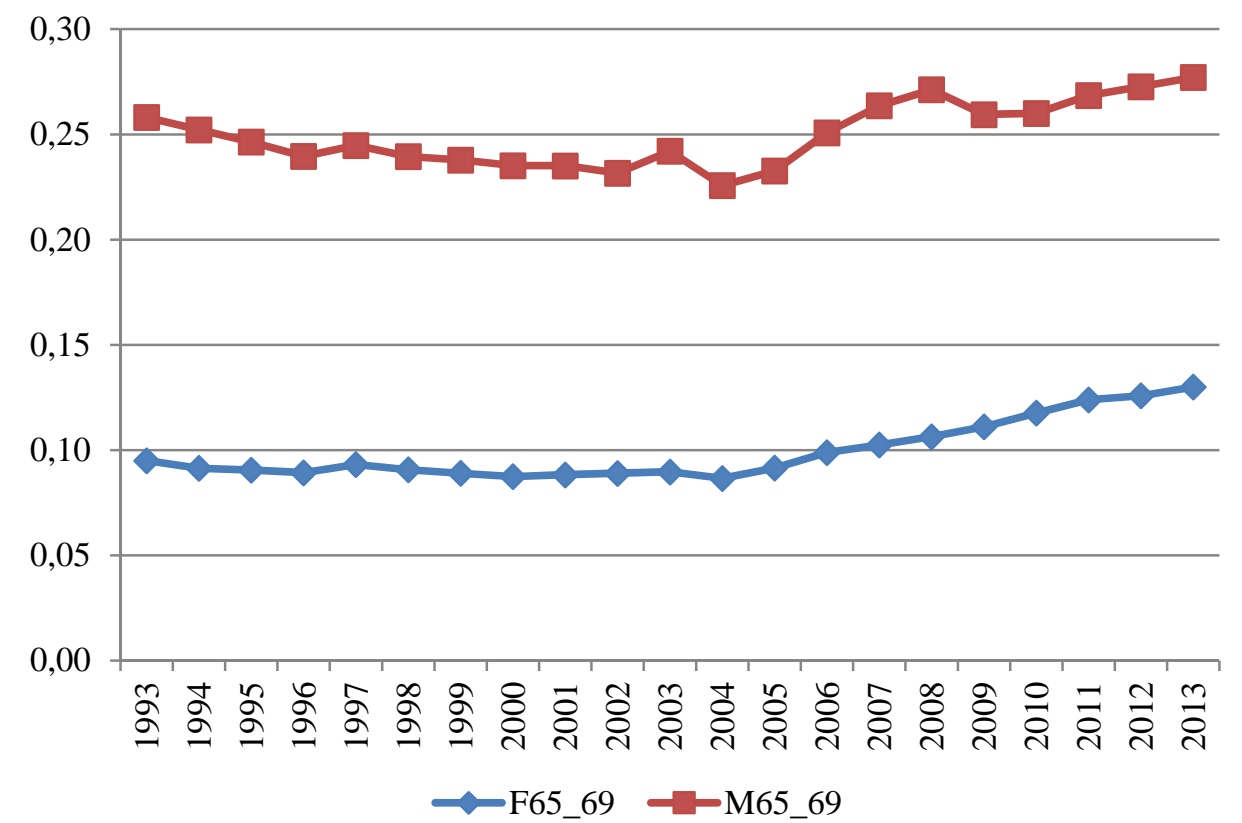

Figure 4. Labor force participation rates, 60-64 years, Norway 1993-2013.

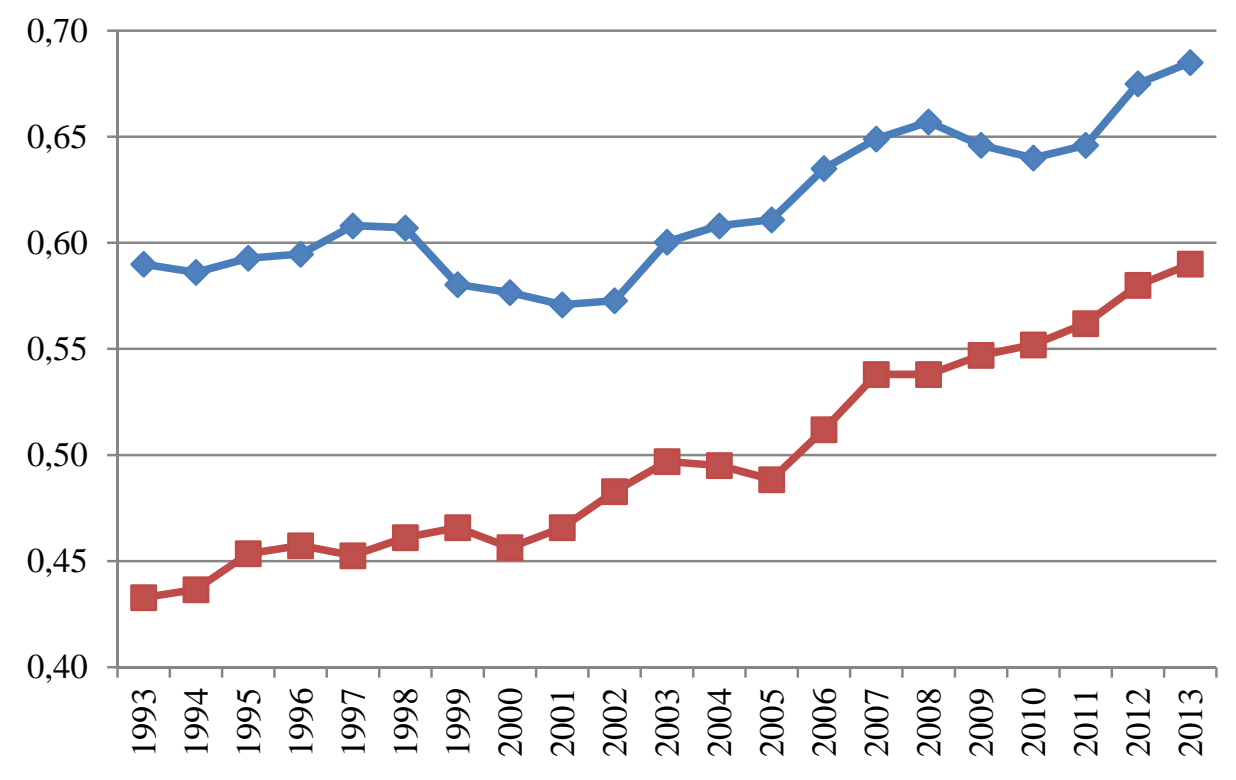

$\leadsto$ Men $\rightarrow-$ Women 
Figure 5. Labor force participation rates, 65-74 years, Norway 1993-2013.

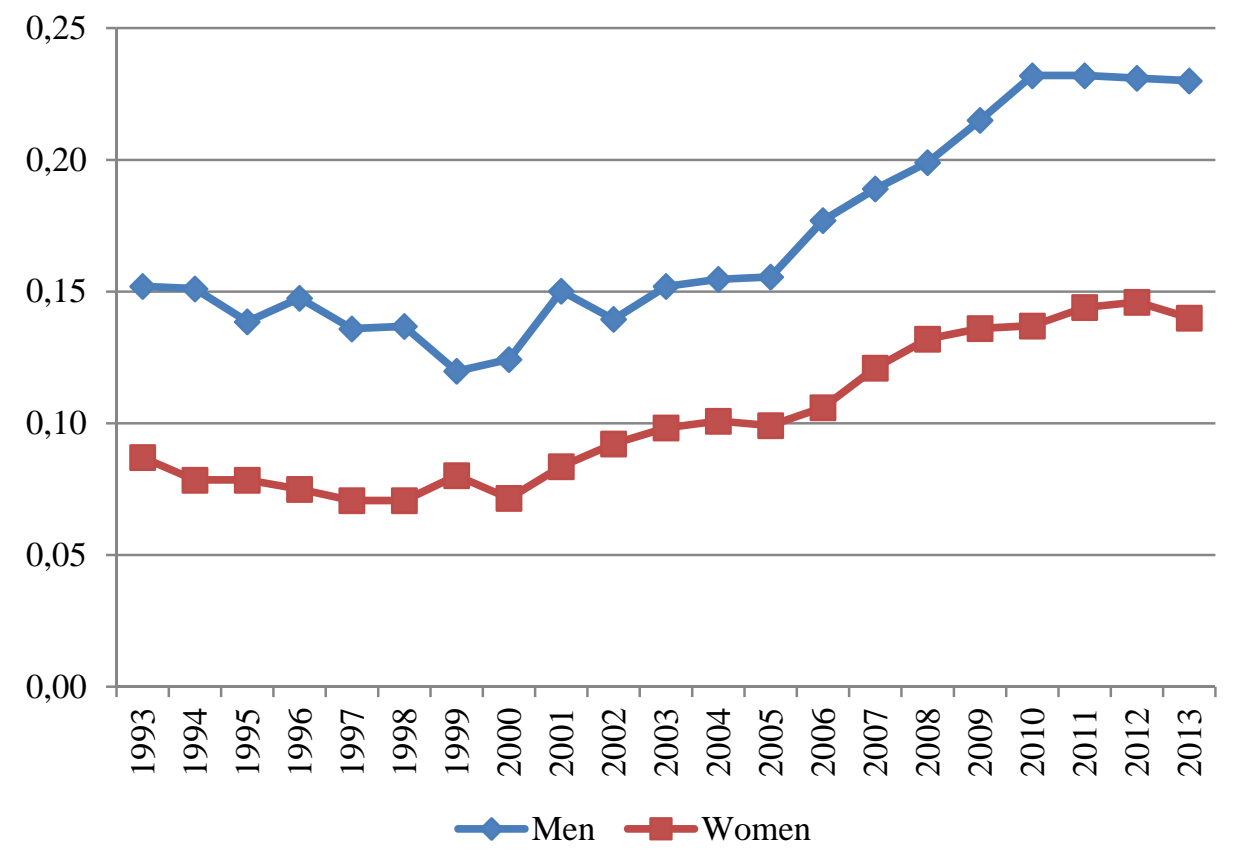

Figure 6. Labor force participation rates, 60-64 years, Sweden 1993-2013.

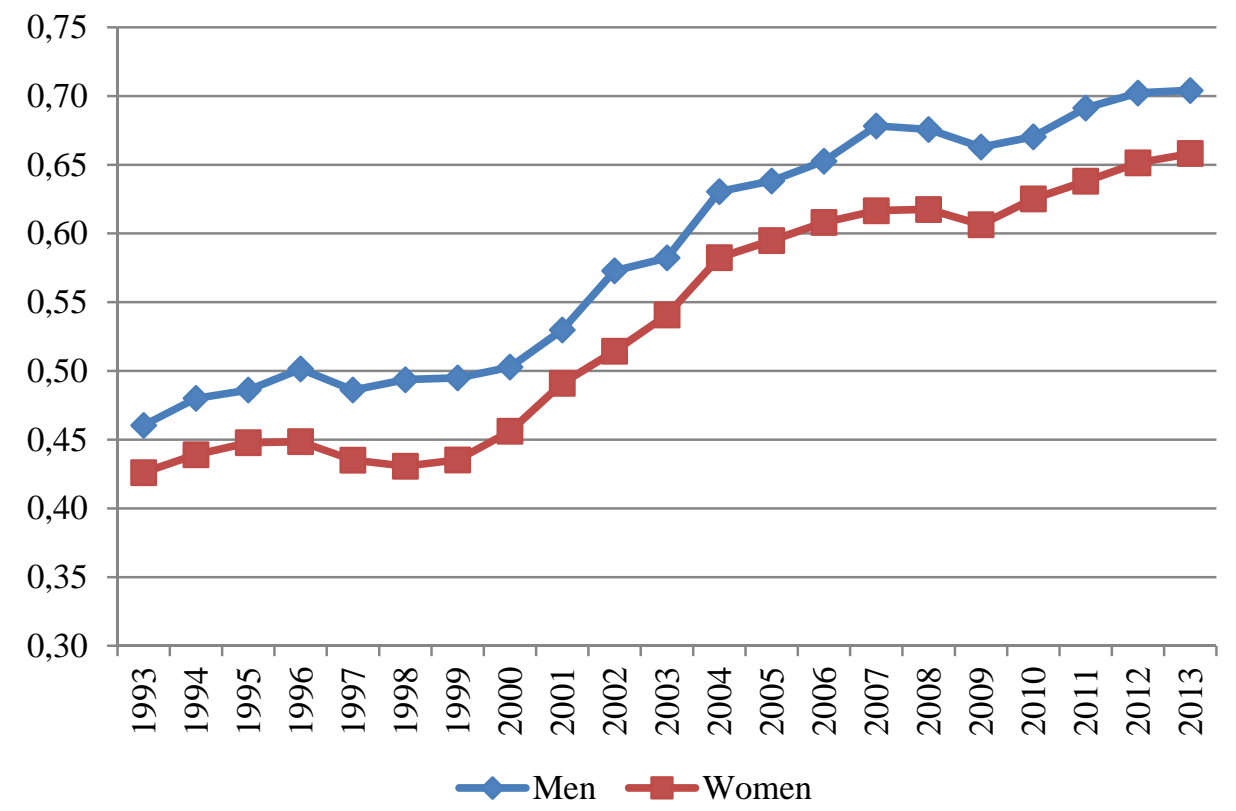


Figure 7. Labor force participation rates, 65-69 years, Sweden 1993-2013.

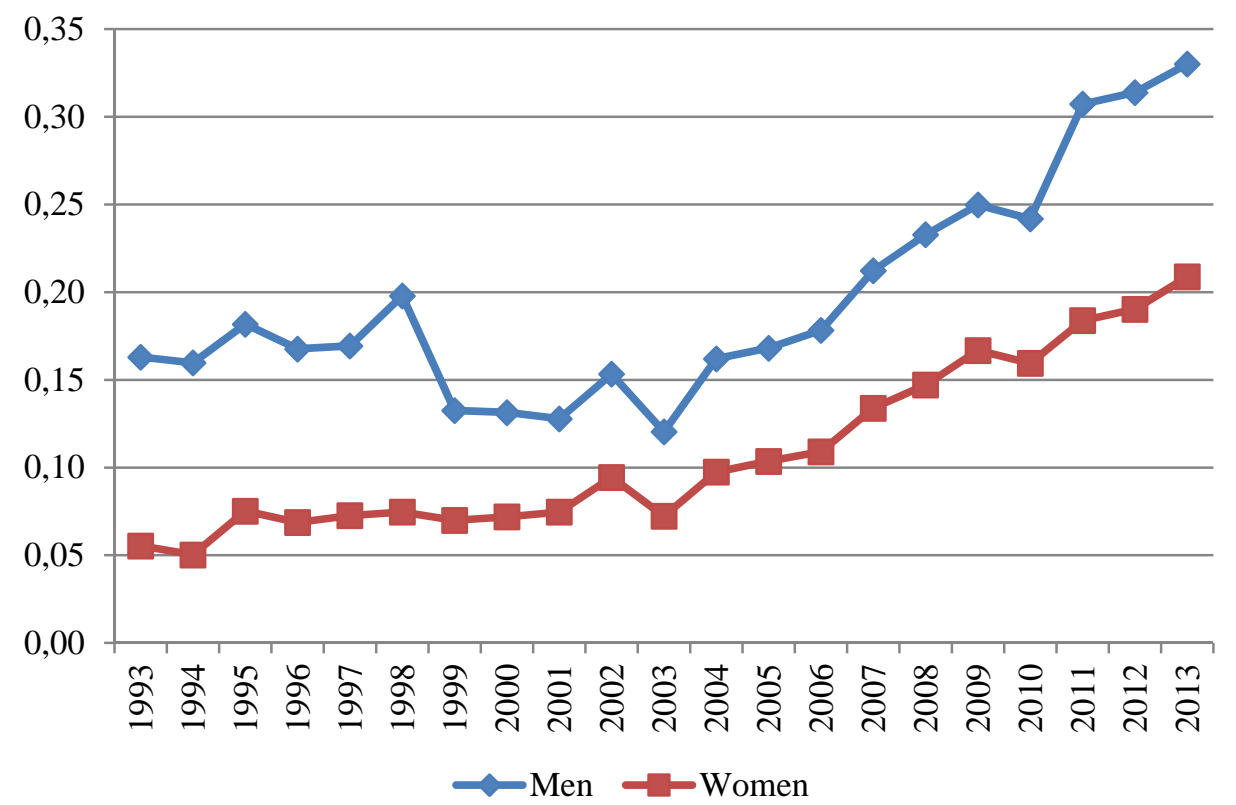

Based on findings in cross section studies using labor force attachment of individuals and on findings in descriptive studies of more aggregate data, the education level and the health status are obvious factors as possible explanations of the strong increase in labor force participation among older workers. In the present case the observation period includes 5 years into the great recession beginning in 2008. In spite of this, labor force participation increases for the 60 and older in the three countries. A small decline in labor force participation is observed for 60-64 years old in Norway and Sweden at the onset of the great recession but in each of the countries the final level in 2013 is higher than before 2008. A prior expectation of a pro-cyclical behavior in labor force participation among older workers is clearly dominated by strong cohort effects supported or accommodated from the demand side. However, individual decisions about retirement or continued work are not only affected by education and health but also by the policy setting concerning rules and programs for early and standard retirement.

In relation to the aggregate trends in Figures $2-7$ we try to measure the impact from education by constructing an educational proxy variable for each year by gender for the two age groups included in the analysis. For this purpose, we use data for the whole population in the relevant age groups by education and construct a weighted indicator for the educational level for each age/gender group. The values for these constructed variables are shown in Figures A3, A5 and A7 in the Appendix along with a brief description of the procedure behind the construction of this variable. In Table 1, we summarize the relative change in this educational indicator by age group, gender and country. In 
Denmark and Sweden, the relative increase has been much stronger for women than for men. This is presumably a cohort effect by gender, which surprisingly does not appear for Norway. In Denmark, 60-64 years old women overtake 65-69 years old men in 2007 with respect to the educational indicator, while they catch up with men in their own age group in 2013, see Figure A3. In Sweden those effects are even stronger, see Figure A7. Here 60-64 years old women overtakes men in the same age group in 1999 while 65-69 years old women overtakes men in their own age group in 2004 and 60-64 years old men by the end of our period.

Table 1. Relative change in education indicator. Denmark, Norway and Sweden, 1993-2013.

\begin{tabular}{|l|c|c|c|c|}
\hline & \multicolumn{2}{|c|}{ Men } & \multicolumn{2}{c|}{ Women } \\
\hline & $60-64$ & $65-69$ & $60-64$ & $65-69$ \\
\hline Denmark & 27.4 & 29.0 & 50.7 & 43.3 \\
\hline Norway & 23.8 & 31.6 & 24.2 & 23.7 \\
\hline Sweden & 30.5 & 32.3 & 44.1 & 49.8 \\
\hline
\end{tabular}

The construction of a simple health indicator is more problematic. The measure we use here for illustration is the life expectancy at age 60 and 65 by gender in each of the countries, see Figures A4, A6 and A8 in the Appendix. This measure does obviously not capture e.g. work related health problems or mental health problems that might influence individual work capacity without necessarily having an impact on life expectancy. On the other hand, the indicator is comparable across the countries. Table 2 shows the relative change in life expectancy by age group, gender and country over the period 1993 to 2013. The main difference is seen to be by gender where the gap in life expectancy between men and women is narrowed during the period. In relative terms the improvement in the health indicator is slightly stronger in Denmark and Norway than in Sweden. 
Table 2. Relative change in health indicator. Denmark, Norway and Sweden, 1993-2013.

\begin{tabular}{|l|c|c|c|c|}
\hline & \multicolumn{2}{|c|}{ Men } & \multicolumn{2}{c|}{ Women } \\
\hline & $60-64$ & $65-69$ & $60-64$ & 13.6 \\
\hline Denmark & 20.9 & 23.1 & 13.0 & 13.2 \\
\hline Norway & 21.9 & 24.4 & 11.5 & 10.6 \\
\hline Sweden & 17.3 & 20.1 & 9.3 & \\
\hline
\end{tabular}

A major expected difference between the educational and the health indicator as correlates for labor force participation is the timing and nature of changes in the two variables. The health indicator measured here by life expectation (or the reverse, mortality) changes fairly slowly over long periods. For instance in Denmark, life expectancy for men 60 years old increases from the mid1980s while life expectation for women - from a higher level - increases from the mid-1990s, see Bingley et al. (2012). The increase in the educational indicator is much more abrupt and dramatic. We try to illustrate this in Figure 8 with the experience in Denmark as an example, building on Undervisningsministeriet (The Ministry of Education,1998). Between the birth cohorts 1936 and 1946, enrolment at longer educations increases dramatically between the years in which these two cohorts were 20 years old, i.e. between 1956 and 1966. For the subsequent cohorts, the increase continues but is much slower in relative terms. Consequently, for the age groups and period in focus here the educational variables show a very steep gradient while the health variable to a larger degree follow a long-term trend towards higher life expectancy. 
Figure 8. The educational indicator. Cohort background. Denmark.

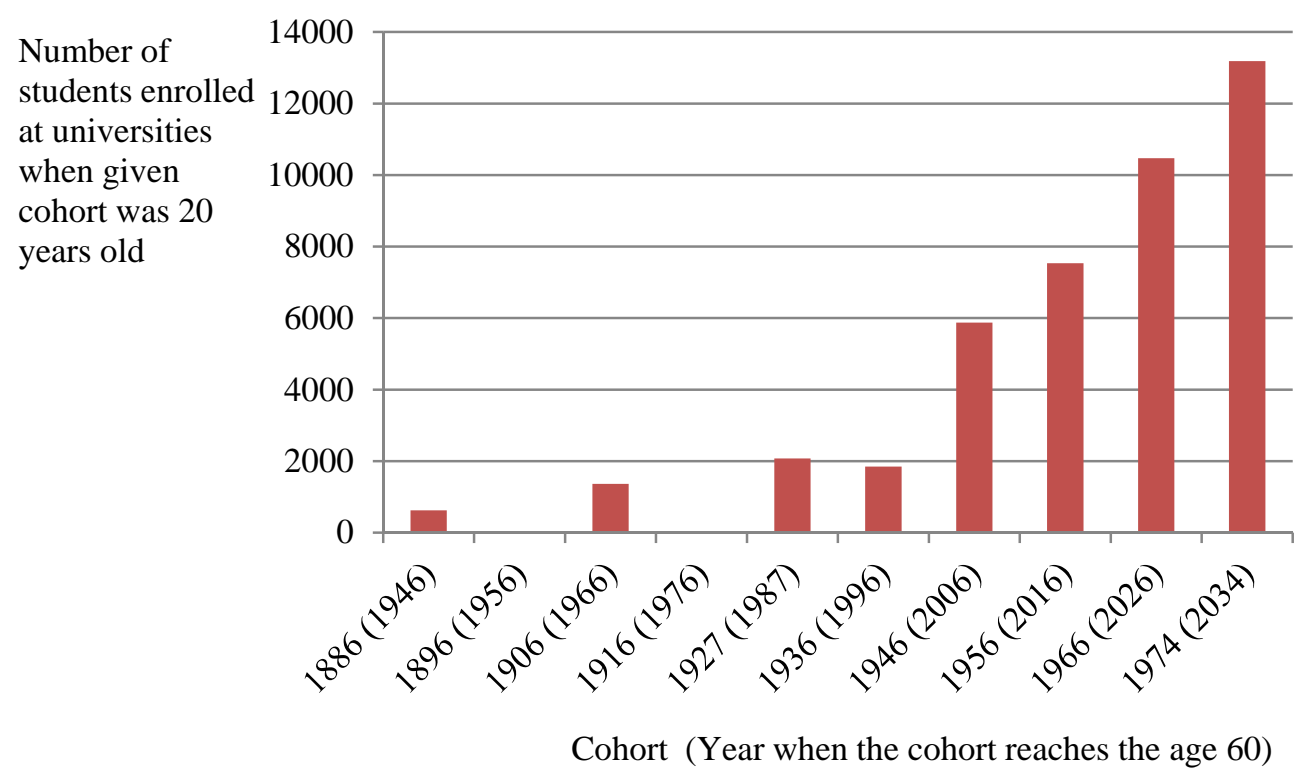

The education indicators above were found by implicitly assuming that the education data available by age and gender groups for the whole population could be applied also to those 60 years and older in the labor force. As there is a positive gradient in labor force participation with respect to education this results in a downward bias in the education indicators in the tables above. Using the Danish register data we have been able to find directly the education level for those in the labor force, however only for the years 1995 to 2012. The change in labor force participation in percentage points for 4 educational groups is shown in Table 3. As individuals with a long further education have the highest initial level of labor force participation it is no surprise that the changes for this group are fairly small, the highest change being an increase of 5.9 percentage points for women 60-64 years old. Overall, the highest increases are found for the group with vocational or short further education. 
Table 3. Change in labor force participation rates, percentage points, by educational groups, Denmark 1995-2012

\begin{tabular}{|l|c|c|c|c|}
\hline & \multicolumn{2}{|c|}{$60-64$ years } & \multicolumn{2}{c|}{$65-69$ years } \\
\hline & Men & Women & Men & Women \\
\hline No post school education & 6.9 & 7.7 & 0.9 & 1.6 \\
\hline Vocational + short further education & 13.6 & 11.6 & 4.0 & 3.0 \\
\hline Medium long further education & 3.4 & 13.4 & -0.3 & 0.8 \\
\hline Long theoretical education & 2.9 & 5.9 & -3.8 & 1.9 \\
\hline
\end{tabular}

These data also enables us to make a simple shift share analysis on the Danish 1995 to 2012 data. The results from this are shown in Figure 9 for the 60 - 64 years old. For women about one fourth of the increase in labor force participation reflects changes in the composition by education while the effect is only half that level for men.

Figure 9. Labor force participation rates, men and women 60-64 years old, Denmark. Actual numbers and standardized for changing composition by education, 1995-2012. Base year 1999.

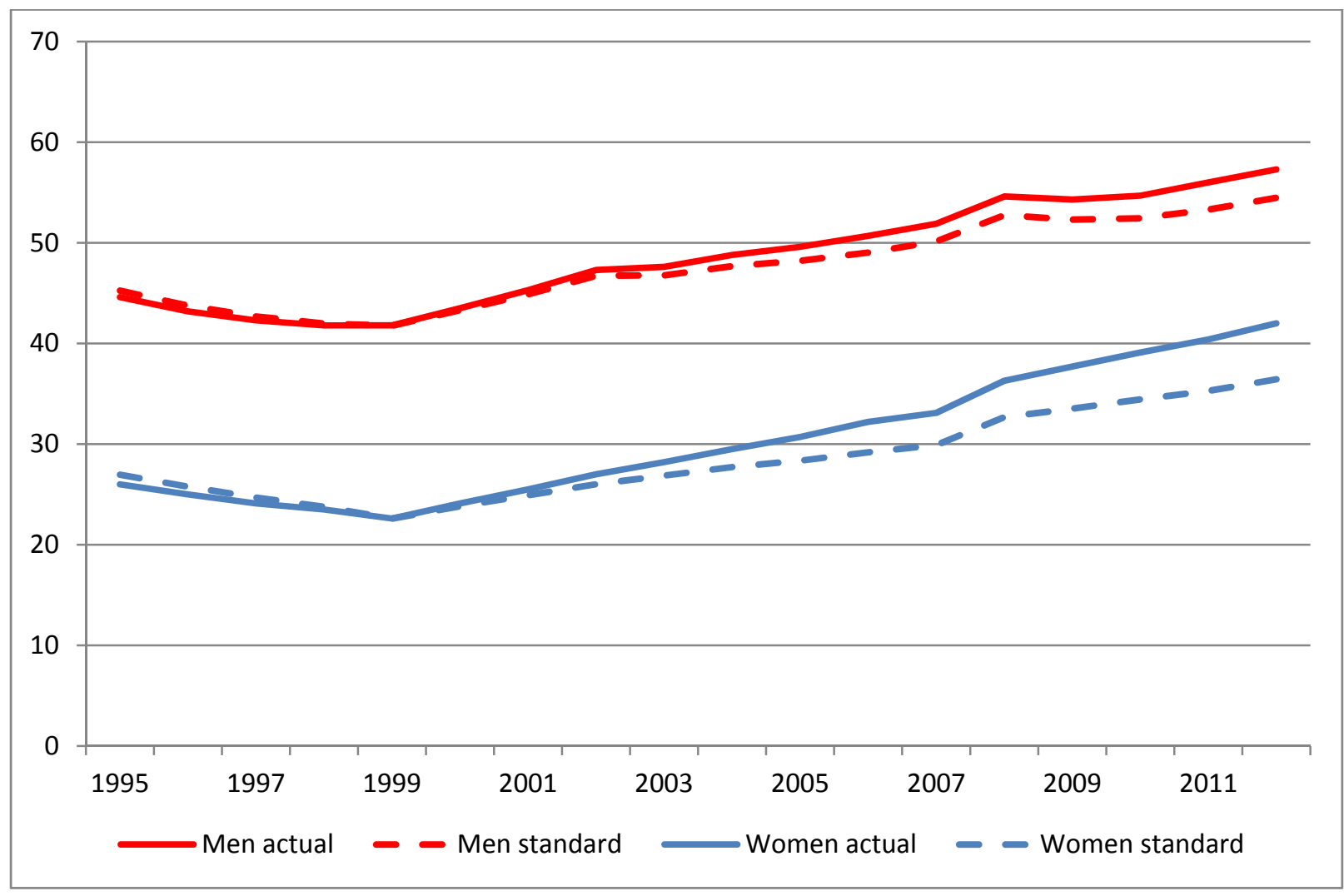




\section{Approaches based on micro data}

In this section we focus on some available micro data to extract supplementary information about the impact of and interaction between education and health relative to labor force participation. We are using data from GSOEP, from SHARE, from DLSA and from ECHP. Only the GSOEP makes it possible to enter both education and self reported health in an estimation using micro data over a longer period. The results from probit estimations on employment for men and women 50 to 70 years old in Germany for 1994 and 2011 are shown in Table 4. Over time we find a small increase in the positive impact from education and an increasing negative impact from a deterioration in health on employment, especially so for women. Comparing the results for men and women we find about the same impact from education and a more equal impact from a deterioration of health.

Table 4. Marginal effects in Probit estimations on being in the labor force, men and women, 50-70 years old, GSOEP, 1994 and 2011.

\begin{tabular}{|l|l|l|l|l|l|}
\hline & Age & $\begin{array}{l}\text { Years of } \\
\text { education }\end{array}$ & $\begin{array}{l}\text { Self assessed } \\
\text { health }\end{array}$ & Pseudo $\mathrm{R}^{2}$ & No. of obs. \\
\hline Men, 1994 & $-0.0778^{* * *}$ & $0.0270^{* * *}$ & $-0.0909^{* * *}$ & 0.3702 & 1870 \\
\hline & -24.26 & 4.83 & -6.02 & & \\
\hline Women 1994 & $-0.0487^{* * *}$ & $0.0210^{* * *}$ & $-0.0366^{* *}$ & 0.2592 & 1894 \\
\hline & -22.59 & 4.12 & -2.93 & & 3698 \\
\hline Men 2011 & $-0.0583^{* * *}$ & $0.0292^{* * *}$ & $-0.1120^{* * *}$ & 0.3307 & \\
\hline & -33.88 & 8.66 & -11.06 & & 4052 \\
\hline Women 2011 & $-0.0593^{* * *}$ & $0.0327^{* * *}$ & $-0.0958^{* * *}$ & 0.3122 & \\
\hline & -34.23 & 9.19 & -9.67 & & \\
\hline
\end{tabular}

Next, the impact from education and self reported health on labor force participation are compared between Denmark, Germany and Sweden in Tables 5 to 7 using SHARE data from wave 4 collected in 2011. Self reported health takes on values from 1 to 5 with 5 being the worst state of health. Tables 5 to 7 reports marginal effects from probit estimations on the probability of being in the labor force from years of education and self reported health separately by gender and two age groups.

As expected most significant marginal effects are found for the 60-64 years old. For education we find for this age group significantly positive effects for men in Denmark and Germany and for 
women significantly positive effects in Germany and Sweden. Self reported health has significantly negative effects in all three countries. For the 65-69 years old we find only few significant coefficients. Education is only found to be significantly positive for men in Denmark, and significantly negative for men in Germany. This might reflect a negative gradient in education in Germany for the 65-69 years old where better educated people retire with a higher propensity than those with little or no education who tend more to continue work for financial reasons. Self reported health is found significantly negative for men in Denmark and for both men and women in Sweden. Overall, the impact from a deterioration of health seems stronger than the impact from a bigger number of years in education.

Table 5. Marginal effects in Probit estimations on being in the labor force, SHARE W4, Denmark

\begin{tabular}{|l|l|l|l|l|l|}
\hline & Age & $\begin{array}{l}\text { Years of } \\
\text { education }\end{array}$ & $\begin{array}{l}\text { Self assessed } \\
\text { health }\end{array}$ & Pseudo $\mathrm{R}^{2}$ & No. of obs \\
\hline Men 6064 & $-0.0857^{* * *}$ & $0.0089^{* * *}$ & $-0.1311^{* * *}$ & 0.1925 & 810 \\
\hline & -8.31 & 3.34 & -11.62 & & \\
\hline Men 6569 & $-0.0540^{* * *}$ & $0.0099^{* * *}$ & $-0.0791^{* * *}$ & 0.1264 & 905 \\
\hline & -6.11 & 4.44 & -6.26 & & \\
\hline Women 6064 & $-0.1311^{* * *}$ & 0.0032 & $-0.0743^{* * *}$ & 0.1598 & 970 \\
\hline & -17.35 & 1.14 & -5.95 & & \\
\hline Women 6569 & $-0.0304^{* * *}$ & 0.0009 & 0.0017 & 0.0440 & 855 \\
\hline & -4.20 & 0.55 & 0.17 & & \\
\hline
\end{tabular}


Table 6. Marginal effects in Probit estimations on being in the labor force, SHARE W4, Germany

\begin{tabular}{|l|l|l|l|l|l|}
\hline & Age & $\begin{array}{l}\text { Years of } \\
\text { education }\end{array}$ & $\begin{array}{l}\text { Self assessed } \\
\text { health }\end{array}$ & Pseudo ${ }^{2}$ & No. of obs \\
\hline Men 6064 & $-0.0662^{* * *}$ & $0.0113^{* *}$ & $-0.1043^{* * *}$ & 0.0568 & 710 \\
\hline & -5.10 & 2,09 & -5.74 & & \\
\hline Men 6569 & $-0.0429^{* * *}$ & $-0.0064^{* *}$ & 0.0064 & 0.0819 & 695 \\
\hline & -5.07 & -2.10 & 0.67 & & \\
\hline Women 6064 & $-0.0921^{* * *}$ & $0.0234^{* * *}$ & $-0.0357^{* *}$ & 0.0728 & 905 \\
\hline & -9.13 & 5.00 & -2.20 & & \\
\hline Women 6569 & $-0.0423^{* * *}$ & 0.0023 & 0.0120 & 0.1636 & 655 \\
\hline & -5.03 & 0.75 & 1.11 & & \\
\hline
\end{tabular}

Table 7. Marginal effects in Probit estimations on being in the labor force, SHARE W4, Sweden

\begin{tabular}{|l|l|l|l|l|l|}
\hline & Age & $\begin{array}{l}\text { Years of } \\
\text { education }\end{array}$ & $\begin{array}{l}\text { Self assessed } \\
\text { health }\end{array}$ & Pseudo $\mathrm{R}^{2}$ & No. of obs \\
\hline Men 6064 & $-0.0546^{* * *}$ & 0.0063 & $-0.0998^{* * *}$ & 0.1163 & 780 \\
\hline & -5.73 & 1.48 & -8.42 & & \\
\hline Men 6569 & $-0.0699^{* * *}$ & 0.0030 & $-0.0763^{* * *}$ & 0.1332 & 1020 \\
\hline & -8.91 & 1.01 & -7.52 & & \\
\hline Women 6064 & $-0.0955^{* * *}$ & $0.0108^{* * *}$ & $-0.1120^{* * *}$ & 0.1471 & 1075 \\
\hline & -11.30 & 3.09 & -11.88 & & 1165 \\
\hline Women 6569 & $-0.0726^{* * *}$ & 0.0012 & $-0.0422^{* * *}$ & 0.2076 & \\
\hline & -9.86 & 0.50 & -5.41 & & \\
\hline
\end{tabular}

For Denmark we do not have a representative annual panel like GSOEP containing information on self assessed health. The Danish Longitudinal Survey of the Ageing is a much more partial panel containing self assessed health among a battery of other information. The survey consists of four waves of data collected every fifth year in the period from 1997 to 2012. From this survey, we obtain information about individuals aged 62 and 67 years with data on self-assessed health. We supplement these data with information from administrative registers on educational level and labor force participation. We distinguish between three educational levels: 1) no post school, 2) 
vocational training and short further education (up to three years) and 3) medium and long further education (at least three years). When measuring self-assessed health, we calculate the share of individuals in "poor health” including those with either "fair”, "poor” or "very poor” health. For individuals aged 62 years, we find as expected that labor force participation has increased from 1997 to 2012 for both men and women in general and also for individuals at all educational levels, see Figure 10. Looking upon the graphs for all 62 years old men and women at all 4 data points we find a slight improvement in self reported health for men along with a quite steep increase in labor force participation. For women self reported health improved until 2007. From 2007 to 2012 we see a steep increase in labor force participation and a slight increase in the share reporting fair-poor health. Looking on educational groups we find roughly the same picture, except a somewhat surprising deterioration in self reported health in the group with the highest level of education. The corresponding graphs for the 67 years old at the 4 data points are left out as they are "noisy" without any clear tendencies.

Figure 10. Labor force participation rates and self assessed health by educational levels, 1997-2012 separately for 62 years old men and women.
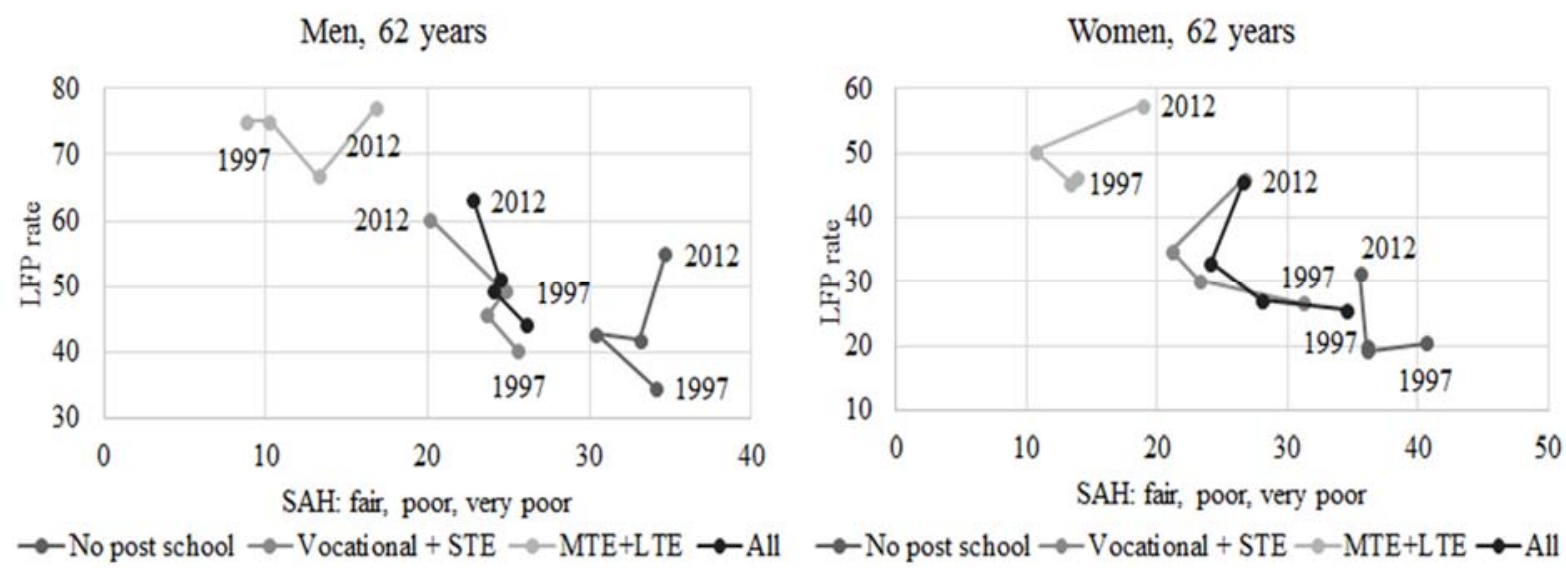

Using GSOEP data for 1994 and 2011 Figure 11 has focus on the relationship between years of education and labor force participation. Figure 11 shows clearly the quite big increase in education for the 50-70 years over these years. The same increase is found for the Scandinavian countries. Further, Figure 11 shows the strong increase in labor force participation, especially in the 60-64 years old group where for instance labor force participation nearly increases with a factor 4 . No clear pattern shows up among the 65-69 years old. 
Figure 11. Years of education and labor force participation rates. GSOEP, Women 50-70 years old, 1994 and 2011.

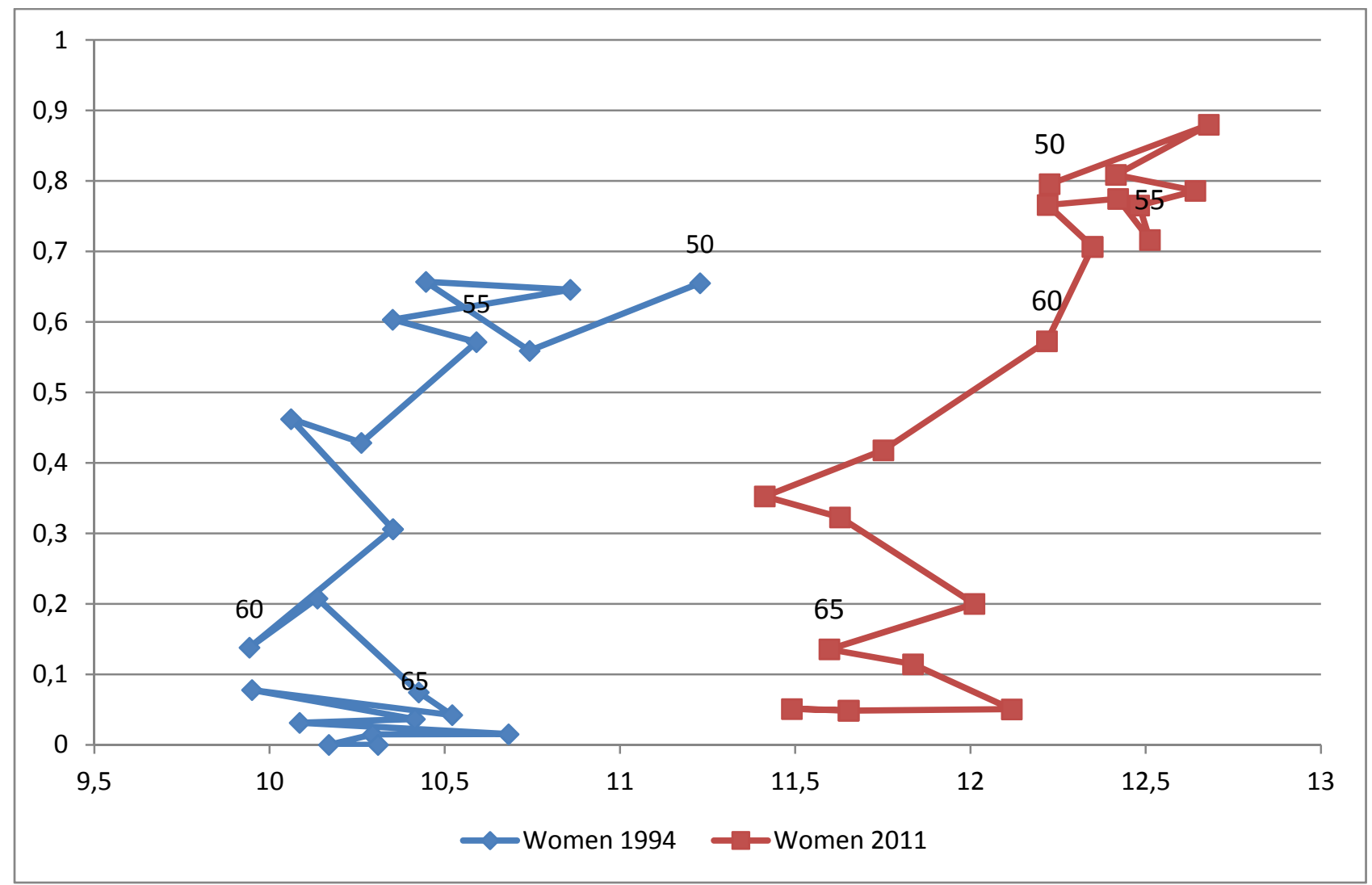

In Figure 12 focus is on the relation between self reported health and labor force participation rates among men 50-70 years old in Germany comparing again 1994 with 2011 based on GSOEP. While the relationships are quite "noisy" among the below 55 and the above 65 years old, a clear increase in labor force participation shows up for individuals in the age group between the mid-50s and the mid-60s, for instance a doubling among the 60 years old. 
Figure 12. Self assessed health and labor force participation rates, GSOEP, Men 50-70 years old, 1994 and 2011.

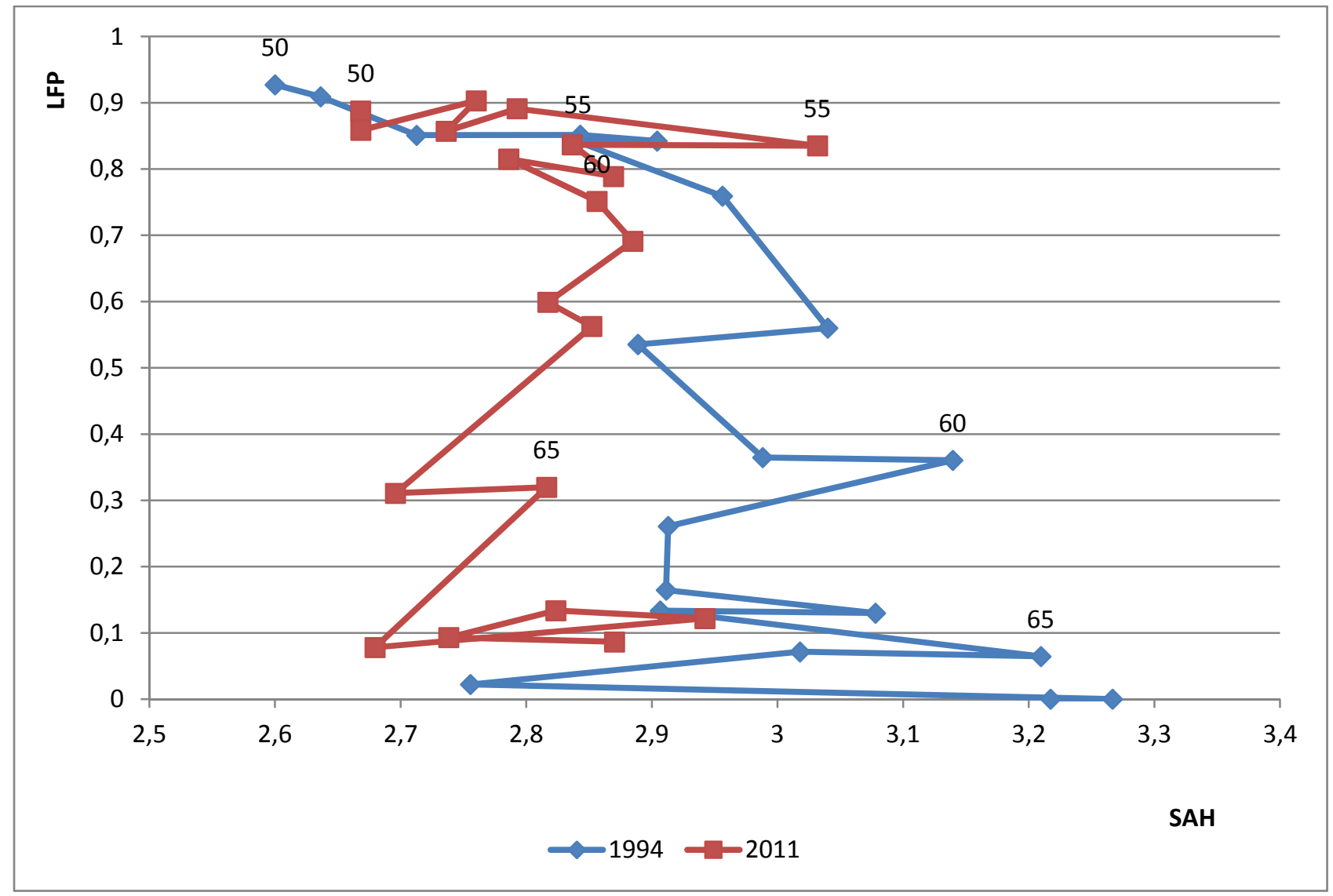

Figure 13 is finally another way of illustrating the complex relationship between labor force participation, self reported health and education. Figure 13 is based on average values over 8 waves of the ECHP for Denmark where the education level is classified in one of the three ISCED groups. It is interesting to note that three, nearly separated, relationships appear between self reported health and labor force participation. The gap in self reported health between the education groups is quite big for people between the mid-50s and the mid-60s. Among individuals in the first half of the 50s labor force participation is significantly lower in the group with least education. For those in the second half of the 60s the main difference found is the much higher labor force participation in the group with the highest level of education. 
Figure 13. Self assessed health, education and labor force participation. Denmark, men 50-70 years old, average over 8 waves of the ECHP, 1994-2001.

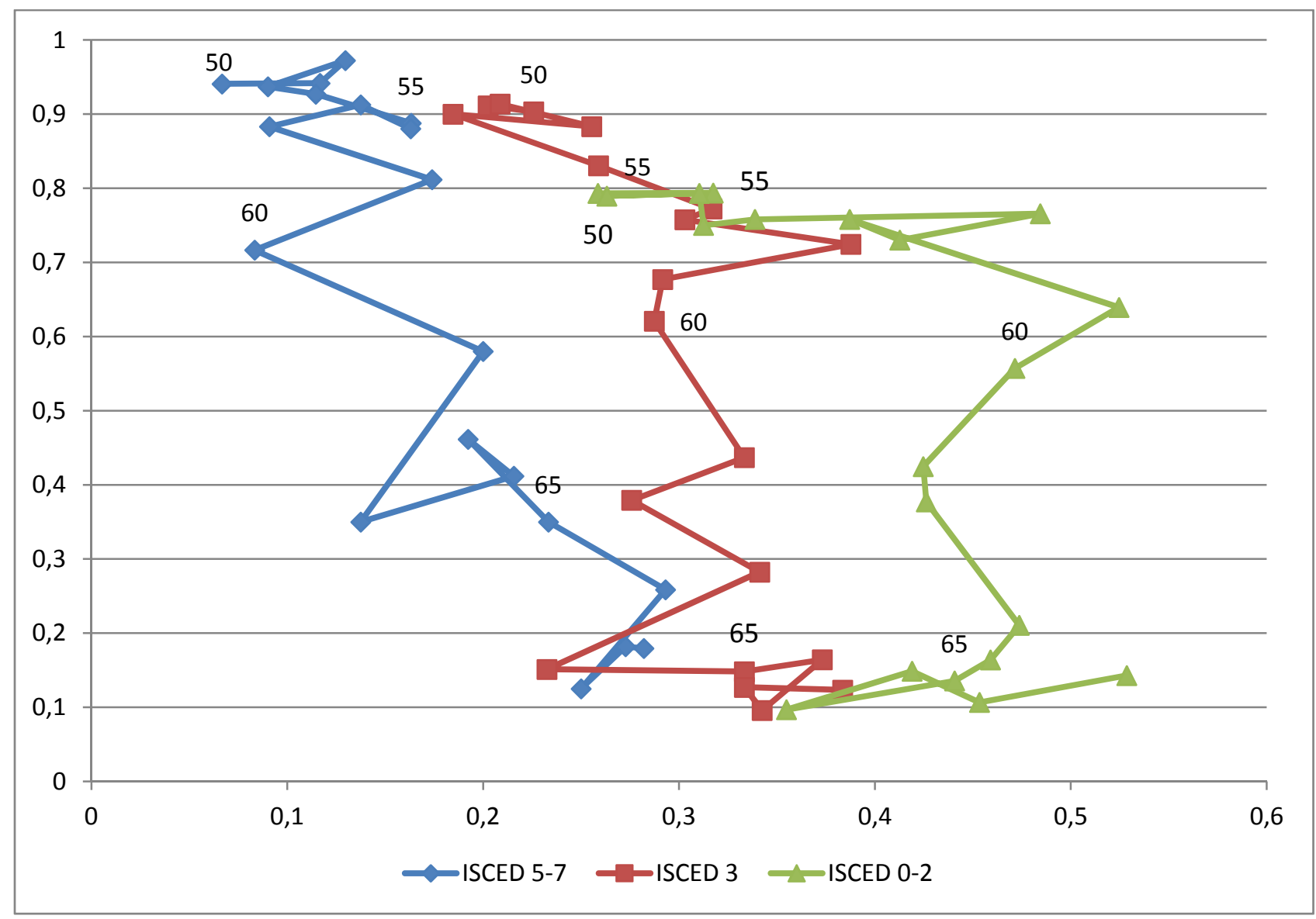

\section{Changes in retirement policies - Scandinavia and Germany}

While health and education are important determinants for continuing work in older ages, policy changes and reforms in the areas of pensions and retirement are also expected to have a significant potential impact. During the years in focus, 1993-2013, many policy changes have been enacted in this area. Here, we include a brief survey.

Until recently, Denmark had a significantly higher share of people in the first half of the 60s in an early retirement program called the "Post-Employment Wage” (efterløn). A major reform was introduced in 1999 intending to reduce economic incentives to enter the program, also by introducing a tax rebate for remaining in the labor force for those eligible for entry. From 2011 other changes reduced the implicit tax inherent in the program for staying in the labor force. Regarding the standard old age pension, it has been made possible to delay entry on actuarial terms from 65 to 75, and means testing against income from work has been reduced. At the same time 
entry to labor market pensions and to private, tax subsidized, pension schemes can be delayed until age 75 on actuarial terms. With a political agreement in 2011 the age of eligibility to PEW will be raised to 62 in 2017 and the State Pension age will be raised to 67 in 2022. After 2022 the State Pension age will be indexed to increases in expected life time.

In Norway a big pension reform was enacted in 2011. Entry to old age pension can occur between ages 62 and 74 on actuarial conditions. Earnings tests for beginning take up of pension are removed and it becomes possible to combine take up of pension with continued work. Finally, the annual pension will be longevity adjusted in the future. While the reform was enacted close to the end of the period we analyze, Midtsundstad (2014) reports that the number of expected years of economic activity among people aged 50 calculated annually from 2001 to 2013 went up 2010 to 2013 as an impact from the 2011 reform. Before the 2011 reform better opportunities for continuing in the labor force with reduced hours were introduced in 2008 and between 2008 and 2011 earnings test was removed for people 67 - 69 years old who received State Pension. This policy change resulted in increasing average hours for people working in this age group.

For Sweden, OECD (2013) shows a big reduction between 1985 and 2009 in the implicit tax on continued work. In 2007, in-work tax credit was increased, with a higher amount for those 65 years and older. The amount of in-work tax credit for older workers was increased again in 2008 and 2009. Finally, both employee payroll taxes and most employer taxes were abolished for people 65 years and older in 2008 and 2009.

In Germany a pension reform was enacted in 2007 resulting in a gradual increase in the age of eligibility for State Pension from 65 to 67 . However, a partial setback to this was a decision to reduce the age from 65 to 63 for specific groups in 2014. In 2004 a sustainability factor was introduced making the current value of old age pension a function of the ratio between pensioners and contributors to the pension program, see Bonin (2009). Bundesanstalt für Arbeit (2013) points to the very steep increase in labor force participation among the 55 to 64 years old, especially among the 60-64 years old where labor force participation doubled from 2002 to 2012, more for women than for men. Bundesanstalt für Arbeit (2013) does not suggest any link between this big increase and changes in retirement programs. The possibility that the big increase in labor force participation reflects a strong increase in the use of the so called mini jobs is not confirmed as mini jobs are not used in the 55-64 years old group above average for the whole adult population. As the share with mini jobs increases with age, these jobs may however contribute to the increase in labor force participation for the 60-64 years old. Overall, it seems that the steep increase in labor force 
participation is a product of a good cyclical situation, of improvements in health and education much more than a reflection of tighter access to retirement programs in Germany in the period we analyze.

\section{Concluding comments}

The starting point for the present analysis is the increase in labor force participation among workers 60 years and older beginning in the late 1990s and surprisingly continuing after the beginning of the great recession in 2008. Focus is on the three Scandinavian countries that follow the trend in most OECD countries of increasing labor force participation for this age group. Throughout the experience in the German labor market is used as a benchmark. We use register based data, labor force surveys and a number of micro data sets in the analyses. For Denmark and Sweden labor force participation for the period 1993-2013 for the 60-64 and 65-69 years old by gender are based on national register data covering the whole population while we use labor force survey data for Norway as Norwegian register data are not available for the whole period. Indicators for education and health are imputed to people in the labor force using data for the whole population in the relevant age-gender groups. For Denmark we have direct data for part of the period on education for those in the labor force.

For all three countries we find a turning point regarding labor force participation around 2000 with the strongest increase in Sweden. This is most pronounced for the 65-69 years old in Sweden for whom a number of specific policy changes have been enacted in recent years with the purpose of increasing continued labor force participation in this age group. The level of labor force participation in 2013 is higher in Norway and Sweden than in Denmark probably due to a Danish program for early retirement to which entry has gradually become restricted during the period by policy changes. The imputed amount of education in the 60-69 years old group in the Scandinavian countries has gone up with at least 25-30\% over the 20 years, for women in Denmark and Sweden the increase has even been in the level of 40-50 \%. Using mortality as a crude health indicator we find increases in the imputed health indicator for those in the labor force around an impressive 20$25 \%$ for men, and at half that level for women. It seems obvious that these two factors are significant determinants for the increase in labor force participation, especially among the 60-64 years old in the period 1993-2013.

In the Danish register data education information is available directly for those in the labor force for most of the period, i.e. the years 1995-2012. For those years the highest increase in labor force 
participation is found for those with vocational and short further education and for women. A shiftshare analysis on the Danish data for this period finds about one fourth of the increase in labor force participation to depend on shifts in the composition of the 60-64 years old by education.

A number of micro data sets are used as an alternative approach to analyze the impact from and interaction between education and health. The micro data have the advantage compared with the data from registers that self reported health status is available for the respondents in the different surveys. The GSOEP is the only one of the micro data sets used that has annual observations over a period matching the length of the register data used in the first part of the analysis. Estimations with GSOEP data for 1994 and 2011 results in finding fairly small increases in the impact from education and an increasing impact from the health variable. Estimations on data from SHARE for Denmark, Germany and Sweden also find most cases with an overall significant impact from health. Separately by gender, education is found more important among men while health is found more important among women. In an analysis on the Danish Longitudinal Survey of the Ageing (DLSA) which is a more partial setup with information on the 62 years old for every five years between 1997 and 2012 we find increases in labor force participation for all educational groups while the picture is more "noisy” regarding health.

Finally, a number of graphic approaches are used. With GSOEP data comparing labor force participation and years of education for women in 1994 and 2011 we observe a very big impact on labor force participation in the 60-64 years old group. GSOEP data for men comparing 1994 with 2011 shows a very strong impact from improved health in the 60-64 years old group. Finally, ECHP data averaged over all 8 waves for Denmark shows an interesting separation of the self assessed health - labor force participation relationship between the three educational groups included in the survey.

Our summary of changes in retirement policies does not make it possible to find any obvious one to one relationship between policy changes and labor force participation. The trend in retirement policy seems to result in a gradual reduction of the implicit tax from continued work from age 60 which has been supportive of the impact from cohort and individual specific increases in health and education. Overall, those three broad determinants for labor force participation from age 60 have contributed significantly to accommodate the demographic change in the coming decades. This is especially the case in Germany where the demographic challenge is much more dramatic than in the three Scandinavian countries. 


\section{References}

Anxo, D., T.Ericson and A. Jolivet. 2012. Working longer in European countries: underestimated and unexpected effects. International Journal of Manpower, 33, 6: 612-628.

Bingley, P., N.D. Gupta and P.J. Pedersen. 2012. Disability Programs, Health, and Retirement in Denmark since 1960. In D. Wise (ed.) Social Security Programs and Retirement around the World, Historical Trends in Mortality and Health, Employment, and Disability Insurance Participation and Reforms. University of Chicago Press.

Bonin, H. 2009. 15 Years of Pension Reforms in Germany: Old Successes and New Threats. IZA Policy Paper No. 11. Bonn.

Brenke, K. 2013. Immer mehr Menschen im Rentenalter sind berufstätig. DIW Wochenbericht Nr. 6, 2013.

Brenke, K. and K.F. Zimmermann. 2011. Ältere auf dem Arbeitsmarkt. Vierteljahrshefte zur Wirtschaftsforschung nr. 2. DIW. Berlin.

Brusch. M. and V. Büsch. 2012. The Role of Job Related Factors to Prolong Working Life: An Analysis for the German Labour Market. Proceedings of the $15^{\text {th }}$ QMOD Conference on Quality and Service Sciences, 09/2012, 272-281.

Bundesagentur für Arbeit. 2013. Ältere am Arbeitsmarkt. Aktuelle Entwicklungen. Nürnberg.

Coile, C. C. and P.B. Levine. 2011. The Market Crash and Mass Layoffs: How the Current Economic Crisis May Affect Retirement. The B.E. Journal of Economic Analysis \& Policy, vol. 11, Iss. 1 (Contributions), Article 22.

Der Spiegel, 2014, Nr. 21.

Dittrich, D., V. Büsch and F. Micheel. 2011. Working Beyond Retirement Age in Germany: The Employee's Perspective, pp. 189-202 in R. Ennals and R.H. Salomon (eds.) Older Workesr in a Sustainable Society. Peter Lang. Frankfurt a. M.

Hochfellner, D. and C. Burkert. 2013. Berufliche Aktivität in Ruhestand. Fortsetzung der Erwerbsbiographie oder notwendiger Zuverdienst? Zeitschrift für Gerontologie und Geriatrie, $46: 242-250$.

Larsen, M. and P.J. Pedersen. 2013. To work, to retire - or both? Labor market activity after 60. IZA Journal of European Labor Studies,2:21.

Midtsundstad, T. and H. Bogen. 2013. Hvordan øke eldres yrkesdeltagelse? Tiltak for å redusere tidligpensjonering i Sverige, Danmark og Finland.(How to increase labor force participation 
among older people? Initiatives in Sweden, Denmark and Finland) Fafo-rapport 2013:04. Oslo.

Midtsundstad, T. 2014. Flexible retirement in Norway. Workshop, Berlin. Fafo Institute. Oslo.

OECD. 2009. Pensions at a glance 2009: Retirement-income systems in OECD countries. Paris.

OECD. 2012. Pensions Outlook 2012. Paris.

OECD. 2013. All in it together? The experience of different labour market groups following the crisis. Ch. 1 in Employment Outlook. 2013. Paris.

OECD. 2014. Pensions Outlook 2014. Paris.

Undervisningsministeriet (Ministry of Education). 1998. Uddannelsessystemet i tal gennem 150 år (The education system in numbers through 150 years). Copenhagen.

\section{Appendix}

Figure A1. Real GDP annual growth. Denmark and Germany, 1993-2013.

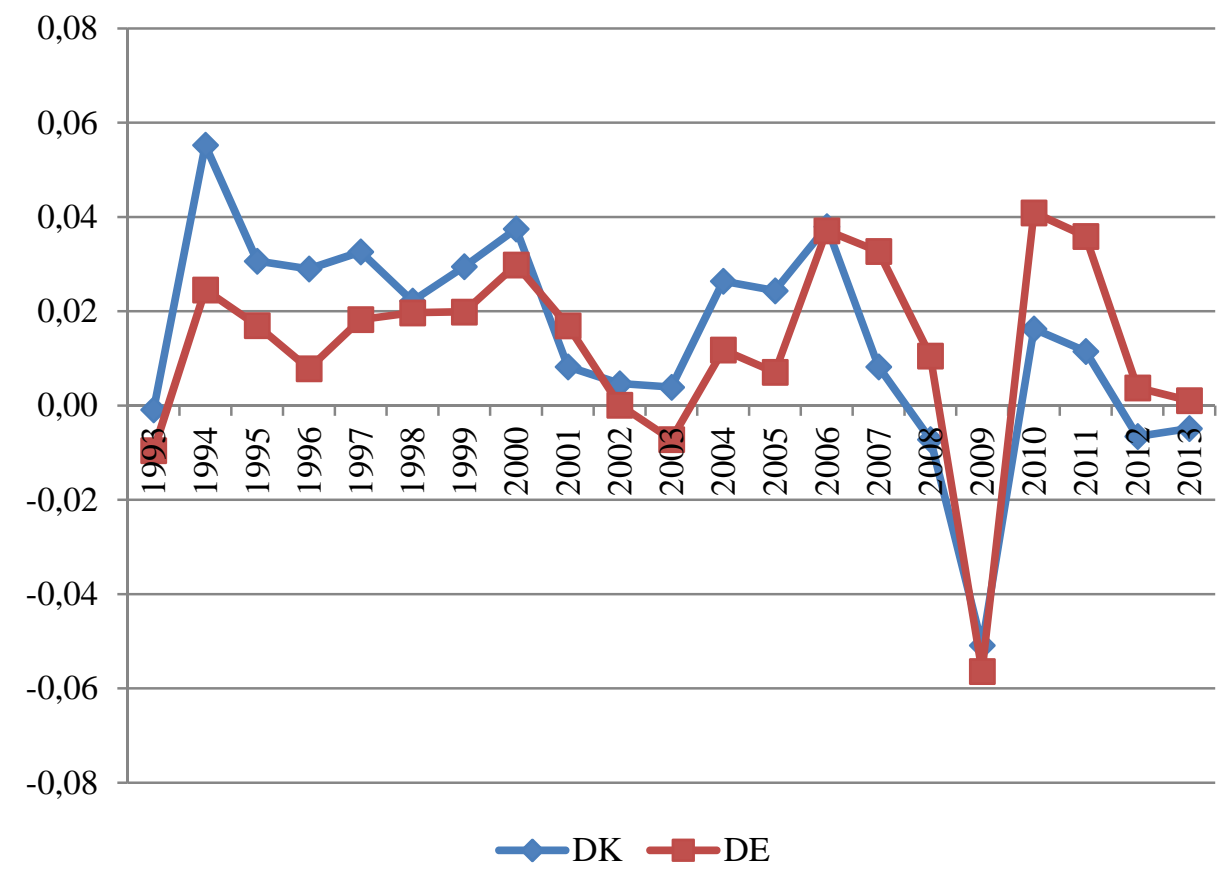


Figure A2. Real GDP annual growth. Norway and Sweden, 1993-2013.

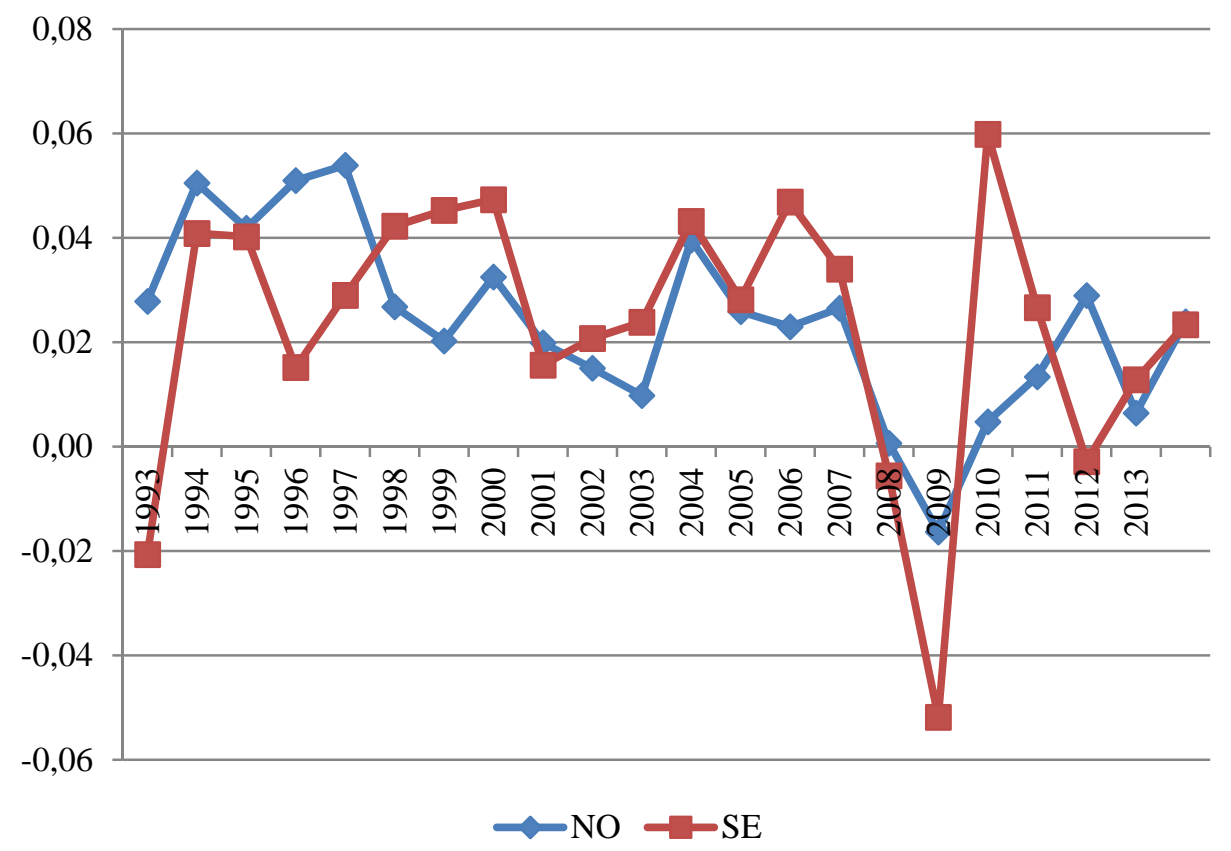

The educational indicators in the graphs below are calculated from register based information regarding the level of education by gender for the whole population 60-64 and 65 -69 years old. For Norway the oldest group consists of the 65-74 years old. For each age gender group the education variable is aggregated to 4 groups, from no post school education to having a long theoretical education. These groups are given the weights 1 to 4 . The weighted indicators shown in the subsequent graphs are based on the implicit assumption that those in the labor force have the same composition on the 4 educational groups as the whole population in the respective age gender groups. If labor force participation has a positive gradient in education, the indicators are biased downwards for those in the labor force. 
Figure A3. Education indicator. Denmark, 1993-2013.

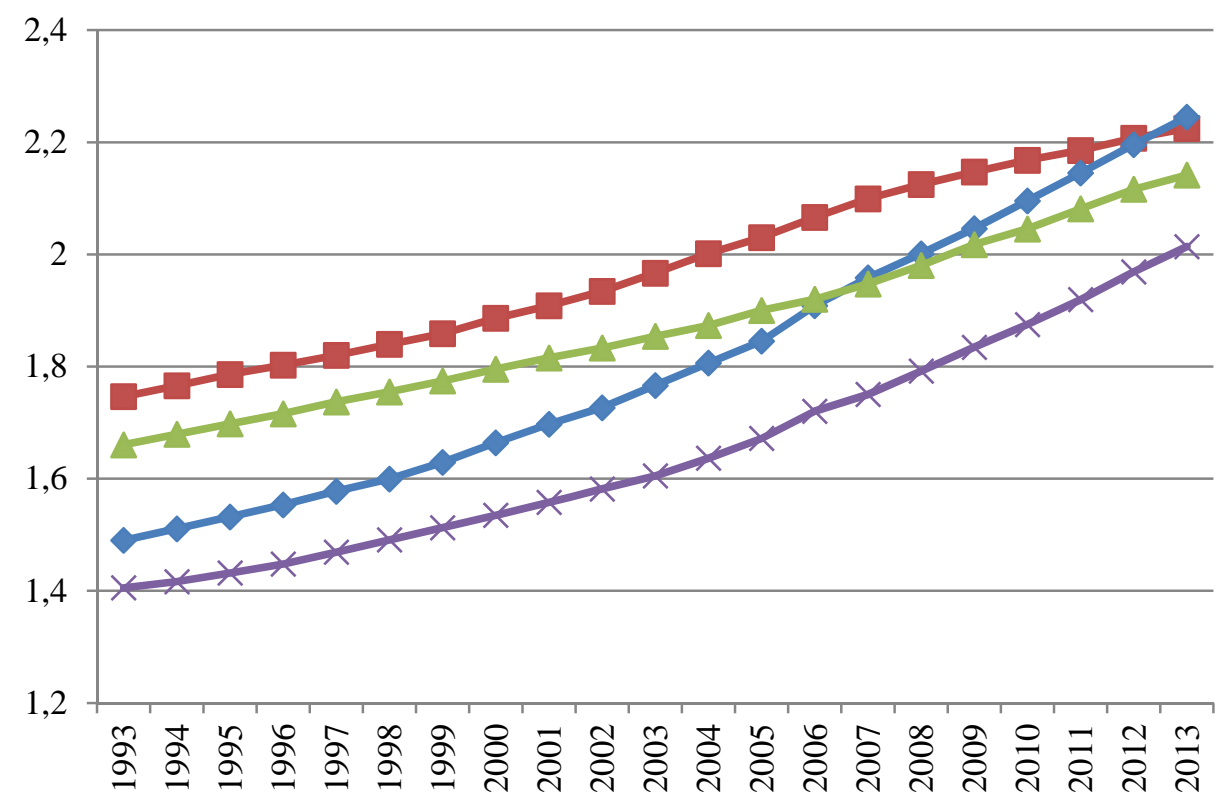

$\leftarrow$ Men 60-64 $\leadsto$ Women 60-64 $\leftarrow$ Men 65-69 $\leftarrow$ women 65-69

Figure A4. Health indicator. Denmark, 1993-2013

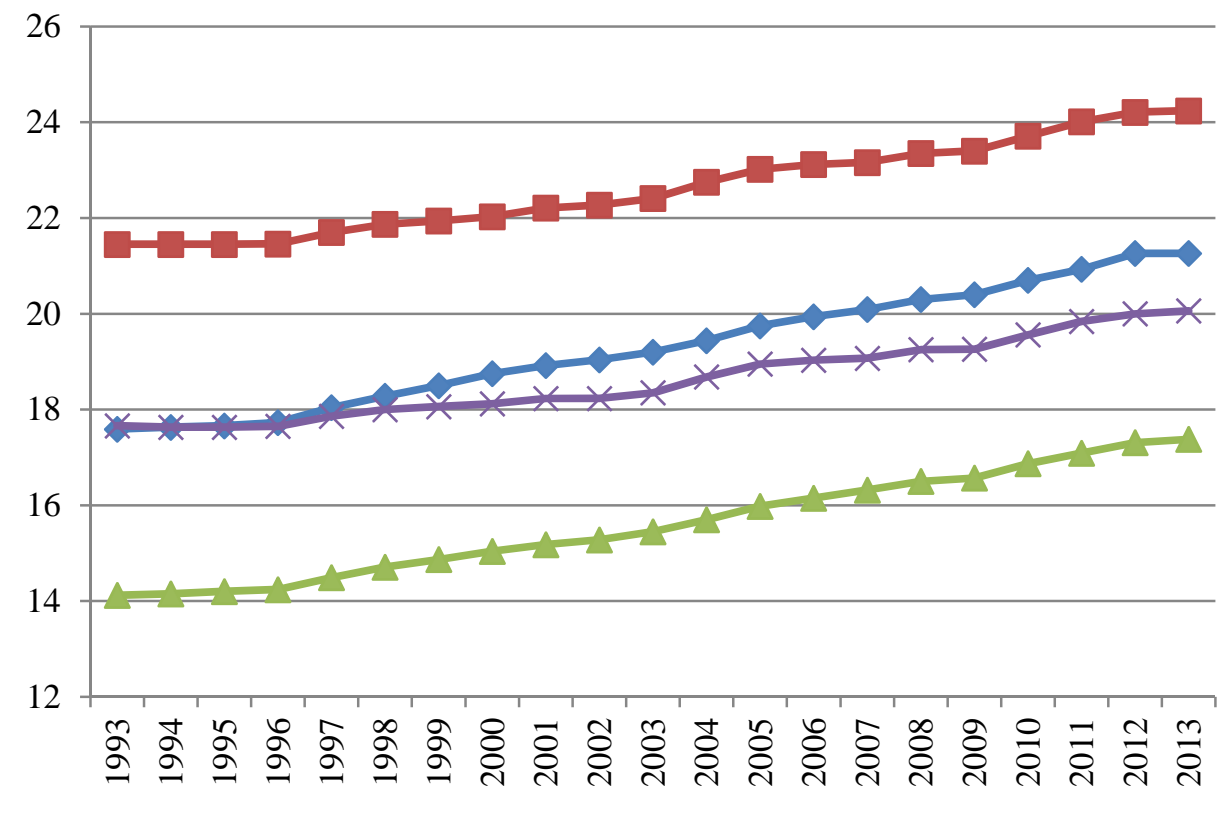

$\multimap$ Men 60-64 $\neg$ Women 60-64 $\leftarrow$ Men 65-69 $\leftarrow$ Women 65-69 
Figure A5. Education indicator. Norway, 1993-2013.

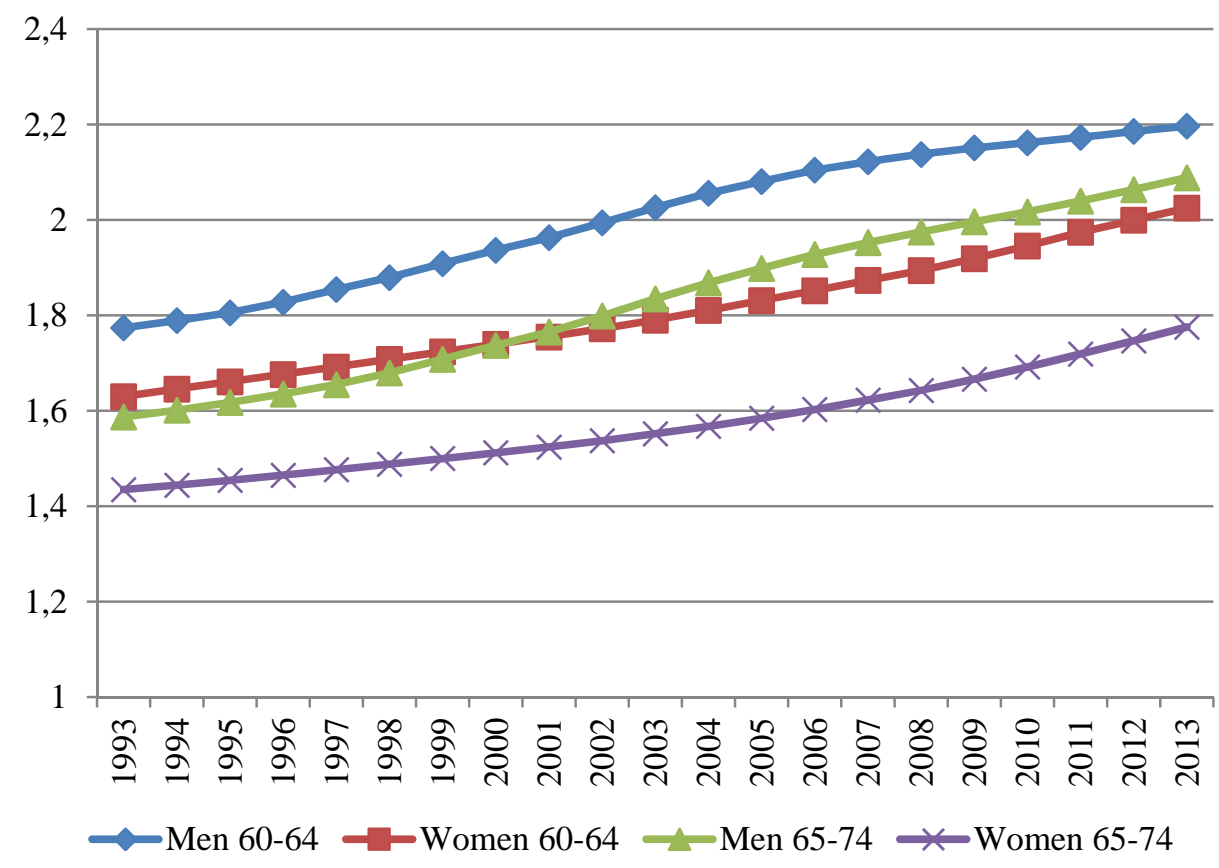

Figure A6. Health indicator. Norway, 1993-2013.

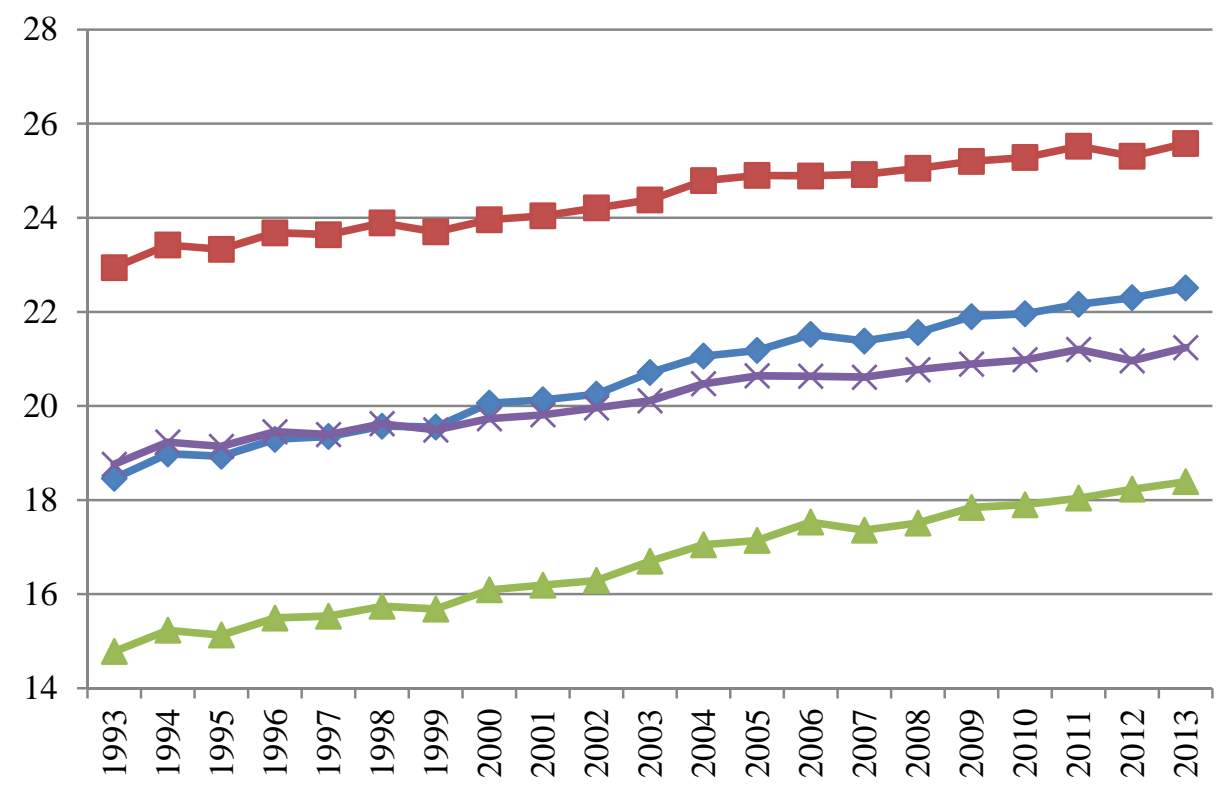

$\leftarrow$ Men 60-64 $\backsim$ Women 60-64 $\leadsto$ Men 65-74 $\longleftarrow$ Women 65-74 
Figure A7. Education indicator. Sweden, 1993-2013.

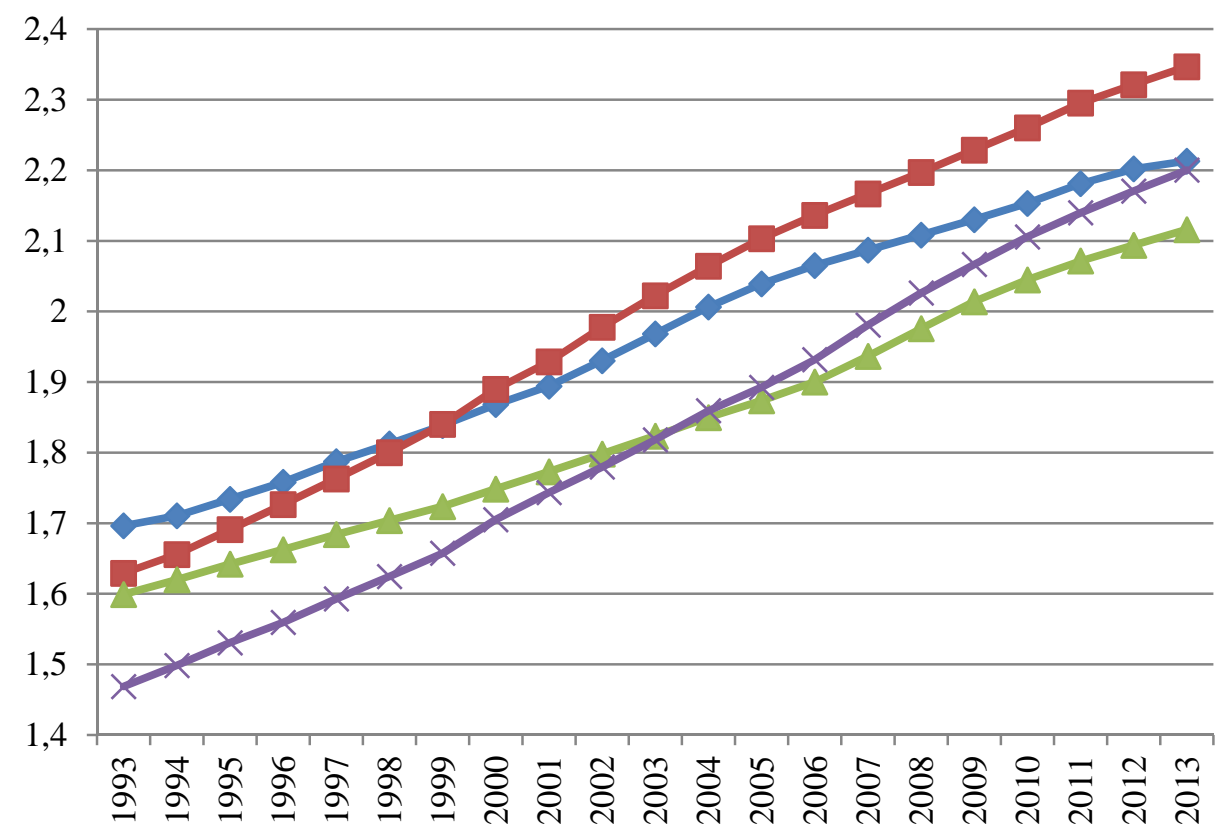

$\multimap$ Men 60-64 $\neg$ Women 60-64 $\rightarrow$ Men 65-69 $\leftarrow$ Women 65-69

Figure A8. Health indicator. Sweden, 1993-2013.

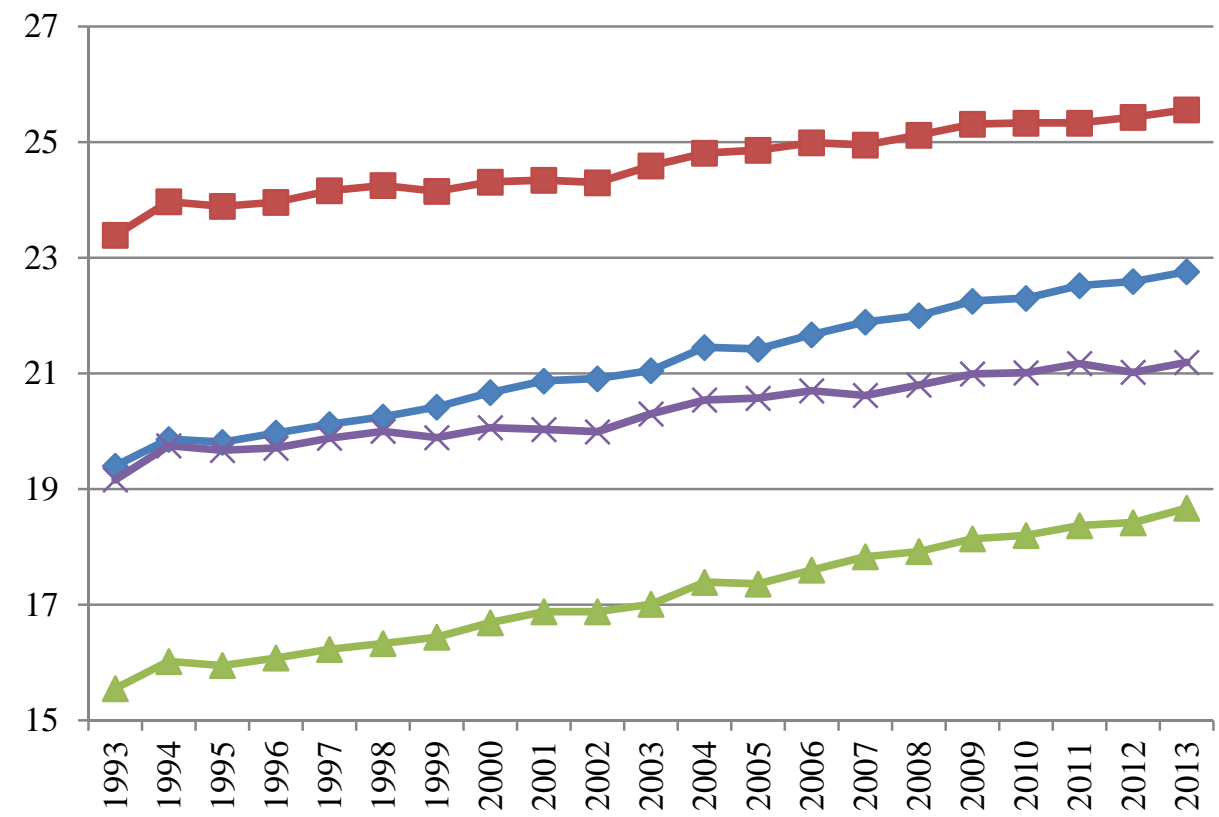

$\leadsto$ Men 60-64 $\neg$-women 60-64 $\leftarrow$ Men 65-69 $\leftarrow$ Women 65-69 